
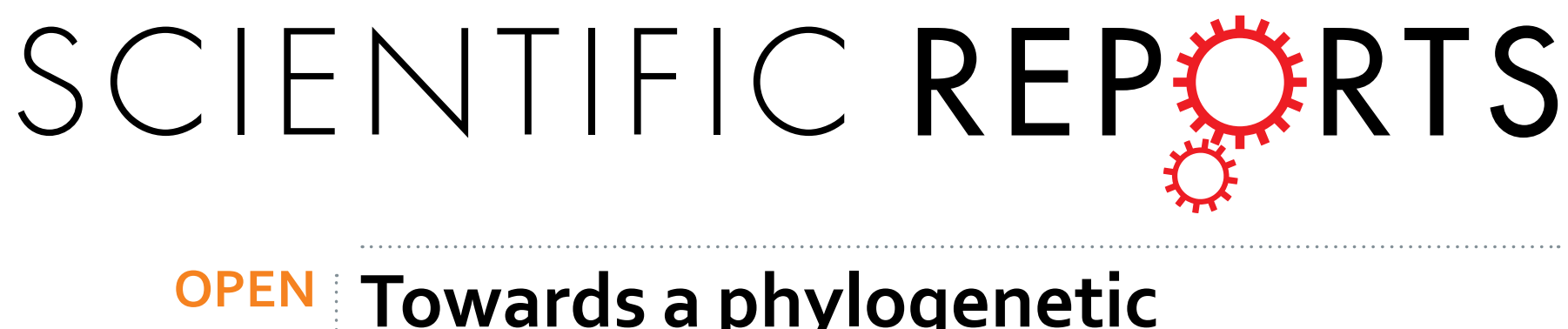

\title{
Towards a phylogenetic classification of Leptothecata (Cnidaria, Hydrozoa)
}

Received: 19 June 2015

Accepted: 03 November 2015

Published: 29 January 2016
Maximiliano M. Maronna ${ }^{1}$, Thaís P. Miranda ${ }^{1}$, Álvaro L. Peña Cantero ${ }^{2}$, Marcos S. Barbeitos ${ }^{3} \&$ Antonio C. Marques ${ }^{1,4}$

Leptothecata are hydrozoans whose hydranths are covered by perisarc and gonophores and whose medusae bear gonads on their radial canals. They develop complex polypoid colonies and exhibit considerable morphological variation among species with respect to growth, defensive structures and mode of development. For instance, several lineages within this order have lost the medusa stage. Depending on the author, traditional taxonomy in hydrozoans may be either polyp- or medusaoriented. Therefore, the absence of the latter stage in some lineages may lead to very different classification schemes. Molecular data have proved useful in elucidating this taxonomic challenge. We analyzed a super matrix of new and published rRNA gene sequences (16S, $18 \mathrm{~S}$ and 28S), employing newly proposed methods to measure branch support and improve phylogenetic signal. Our analysis recovered new clades not recognized by traditional taxonomy and corroborated some recently proposed taxa. We offer a thorough taxonomic revision of the Leptothecata, erecting new orders, suborders, infraorders and families. We also discuss the origination and diversification dynamics of the group from a macroevolutionary perspective.

Leptothecata Cornelius, 1992 is the most speciose clade within Medusozoa Petersen, 1979, with approximately 2,000 nominal species described, corresponding to more than half of the richness of Medusozoa ${ }^{1-3}$. Historically, its taxonomy has been based on diverse morphological characters of the benthic (polyps and colonies) and planktonic stages (medusae; see reviews in Cornelius ${ }^{4,5}$ ). The original diagnosis of Thecata was remarkably based on exoskeletal characters of polyps, mainly the hydrotheca and the gonotheca: "Polypi surrounded by a membranaceous tube, covering the subdivisions of their compound body" (Fleming ${ }^{6}$, p. 505). The metagenetic life cycle in Medusozoa was described thereafter ${ }^{7}$, with consequences for the taxonomic arrangement due to a dual classification system, one for polyps and another for medusae.

Subsequently, Thecaphora was proposed by Hincks $(1868)^{8}$ as "Hydroida furnished with thecae" (p. lxvii) and "The chitinous receptacle in which the polypites are lodged in one of the Hydroid suborders (Thecaphora)" (p. iii), along with the description of several suprageneric taxa (e.g., Campanulinidae, Haleciidae and Lafoeidae). The classification was also based on skeletal characters of the polyps and, when present, on the medusa stage. Classification problems were recognized for some groups, including uncertainties due to the lack of information on the life cycle of the polyp and the medusa stages $\left(\right.$ Allman $^{9}$, Hincks $^{8}$, Cornelius ${ }^{10}$, Calder $\left.{ }^{11}\right)$. In 1871, Allman ${ }^{12}$ proposed the taxon Calyptoblastea based on characters of the skeleton surrounding the polyp stage and variations in the life cycle: "Calyptoblastic ([...] covered; [...] bud). The condition of a hydroid when an external protective receptacle (hydrotheca or gonangium) invests either the nutritive or generative buds. CALYPTOBLASTEA, the name of one of the sub-orders of HYDROIDA" (1871, p. xvii, all capitals in the original $)^{12}$.

Based on the medusa stage, Haeckel ${ }^{13}$ proposed the taxon Leptomedusae and several other suprageneric taxa (e.g., Eirenidae, Mitrocomidae). This proposal strengthened a parallel classification scheme, with some studies based only on the polyp stage, and others only on the medusa stage.

${ }^{1}$ Departamento de Zoologia, Instituto de Biociências, Universidade de São Paulo Rua do Matão Trav. 14, 101, 05508-090, São Paulo, Brazil. 'Instituto Cavanilles de Biodiversidad y Biología Evolutiva, Departamento de Zoología Universidad de Valencia, Valencia, Spain. ${ }^{3}$ Departamento de Zoologia, Caixa Postal 19020, Universidade Federal do Paraná, 81531-990, Curitiba, PR, Brazil. ${ }^{4}$ Centro de Biologia Marinha, Universidade de São Paulo, São Sebastião, Brazil. Correspondence and requests for materials should be addressed to M.M.M. (email: maxmaronna@gmail. com) 
Broch ${ }^{14}$ split the leptothecates into Conica (species with conical hypostome and without pre-gastric cavity) and Proboscoida ("Proboscoidea" p. 224, species with globular hypostome and pre-gastric cavity). With few exceptions (e.g., Rees ${ }^{15}$ ), this dual classification predominated until the second half of the $20^{\text {th }}$ century, when Naumov ${ }^{16,17}$ aimed at an integrative approach ${ }^{18}$, highlighting that "...to create such a unified classification of medusae and polyps, accurate data is needed on the individuals of different generations indicating that they belong to the same species..." (Naumov ${ }^{17}$, p. 94). This proposal, along with Hincks ${ }^{8,19-21}$, Allman $^{9,12}$, Morton ${ }^{22}$, and Rees ${ }^{15}$, reinforced a classification of Hydrozoa that was maintained until the end of the $20^{\text {th }}$ century (viz., Millard ${ }^{23}$; Cornelius ${ }^{24}$; Bouillon $^{25,26}$; Petersen ${ }^{27}$ ). The main taxonomic change along this period was the fusion and definition of names based on polyps and medusae, although these decisions were inconsistent with the classification of Hydrozoa at the time ${ }^{25,26}$ (summary in Table 6 of Bouillon ${ }^{28}$, p. 266). Later, this classification was intensively criticized and only partially accepted (Cornelius ${ }^{4,5}$; Bouillon \& Boero $^{29}$; Bouillon et al..$^{30}$ ).

Finally, the name Leptothecata Cornelius, 1992 (Cornelius $^{31}$, p. 246) was proposed as an alternative to synthesize the taxa "Leptomedusae" + "Thecatae" as a counterpart to Anthoathecata, "Anthomedusae" + "Athecatae". At the same time, other phylogenetic hypotheses for Hydrozoa were proposed, based on morphological ${ }^{32,33}$ and molecular $^{34}$ analyses, as well as important studies challenging the status of many taxa, including Leptothecata itself. In the past decade, identification and corroboration of major hydrozoan lineages were accomplished, although the main relationships among them were not conclusive (e.g., Hydroidolina ${ }^{35}$; Trachylina ${ }^{36-38}$ ).

Leptothecata has always been considered a monophyletic $\operatorname{taxon}^{32,34,35,39}$. Nevertheless, additional hypotheses for internal relationships based on molecular (Campanulariidae Johnston, $1836^{40}$; Plumularioidea McCrady, 1859 ${ }^{41,42}$; Lafoeidae A. Agassiz, 1865 and Hebellidae Fraser, 1912 ${ }^{43}$ ) and morphological analyses (Lafoeidae and Hebellidae $^{44}$ ) challenged the monophyly of several of those taxa. A landmark leptothecate phylogeny incorporated important new taxa and recovered two main clades, Statocysta and Macrocolonia ${ }^{45}$. We assessed, reviewed and discussed phylogenetic hypotheses from these recent studies, including those in which new family-level groups were recognized (e.g., Schizotrichidae ${ }^{46}$ ).

Clearly, the existence of the polyp and the medusa stages creates complex issues for taxonomic interpretation. The current phylogenetic context obtained from molecular analyses points to obvious conflicts concerning classification and the current interpretation of macroevolutionary patterns, such as the evolution of the polyp skeleton in the Proboscoida clade and medusa traits in Statocysta. Thus, unresolved questions remain for both ecology and evolution of Leptothecata and demand a more thorough analysis, considering phylogeny, classification and taxonomy. Therefore the goals of this study are (1) to propose a phylogenetic hypothesis using molecular data from the largest set of Leptothecata sequences assembled so far; (2) to compare this hypothesis with other hypotheses proposed in the last 20 years; (3) to propose a new taxonomic classification for the order and (4) to briefly discuss some macroevolutionary considerations about the Leptothecata, mainly considering the large-scale phylogenetic patterns in morphology and biology that have become evident as a consequence of the proposed hypothesis.

\section{Results}

The combined datamatrix of ribosomal markers 16S, 18S and 28S, with light data filtering (herein 16S18S28S_N), is our working hypothesis (Fig. 1, Tables 1-4) because it offers the greatest support values for the majority of basal nodes. Unfiltered (Fig. 2) and heavily filtered (Fig. 3) results are presented for comparison among noise filtering levels. Analyses based on different combination of matrices and noise filtering are presented in Tables 1 and 2 and Supplemental Material (Text and Figs. 3-12), and a small number of contrasting patterns are dissected in the discussion section.

Basal clades and species whose topological placements were unresolved or whose placements were strongly supported, but conflicting across different topologies, were called "Lineages" (marked with the letter L; Figs 1-4, Table 2). Rogue taxa (marked in our topologies with letter R), on the other hand, are those terminals whose positions vary widely among the pseudo-replicates generated by nonparametric bootstrap analysis (see Methods section). Such instability leads to an overall decrease in bootstrap support across clades summarized by a consensus tree. Rogue taxa will, by definition, be poorly supported by bootstrap analysis, but they may be significantly supported by the other methods employed in this study (see Methods section). Four rogues (Hydrodendron gardineri - R 1, Opercularella lacerata - R 2, Billardia subrufa - R 3 and Scandia gigas - R 4) had substantially different placements across topologies (Figs 1-3). Hence, they were considered Leptothecata incertae sedis and excluded from the new taxonomic proposal.

Outgroups. Most of the outgroups (Table S1) were monophyletic in the combined analyses (e.g., Aplanulata ${ }^{47}$ Figs 1-3). A filiferan clade (including groups III and IV) was recovered as the sister group of Leptothecata in analyses of low-filtering and unfiltered matrices (Figs 1 and 2). However, Siphonophorae is sister group of Leptothecata according to the analysis of the highly filtered matrix (Fig. 3). In all cases, support values for those relationships were low.

Main clades of Leptothecata, some rogue taxa and "traditional lineages". The most basal taxon of Leptothecata includes species of Lafoeidae (Lafoea dumosa and Acryptolaria conferta) and Hincksella sp. (Syntheciidae), comprising the clade Lafoeida sensu novum (with stable basal position and high support; Figs 1-3; Tables 2 and 3) plus Lineage 1 (L 1), which has low support and includes species of Campanulinidae and Melicertidae (Stegella lobata and Melicertum octocostatum, respectively). Laodiceida taxon novum is another well-supported clade with stable position, including species of Laodiceidae (monophyletic if Staurodiscus gotoi is not considered) and Tiarannidae (not monophyletic). Laodiceida is the sister group of main clade comprising Lineage 2, Statocysta, Macroloconia and also, includes the rest of lineages (L 3 to L 5) and rogue taxa (R 1 to R 4) (Figs 1-3). 

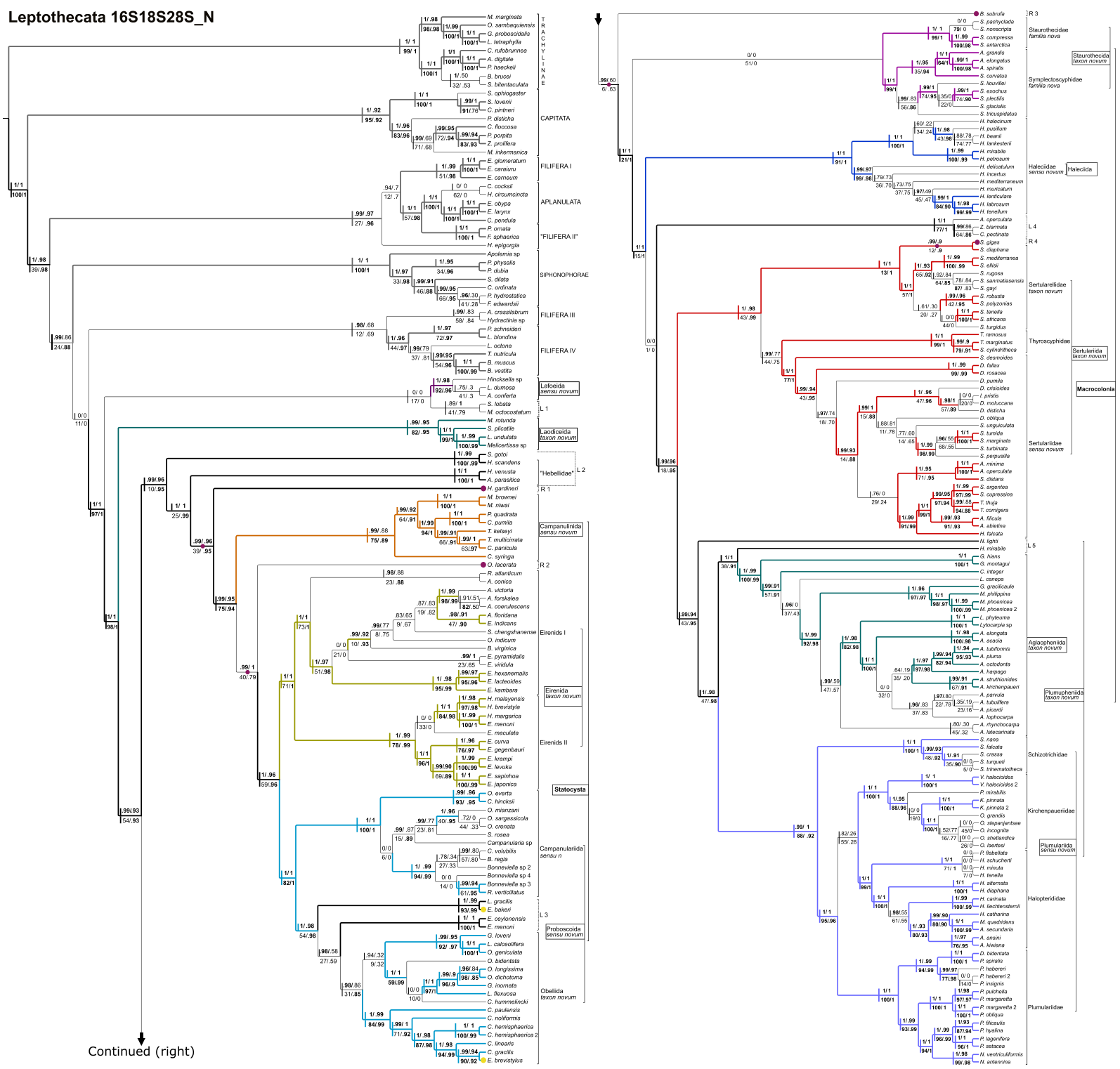

Figure 1. Cladogram of the phylogenetic analysis of Leptothecata with minimum filtering (matrix 16S18S28S_N). Support values are integer numbers or decimals (no leading zeros). Parametric support above the branch (aBAYES/aLRT), non-parametic support below the branch (BS/SH-aLRT); values in plain text indicate non-significant support (aBAYES $<0.95$; aLRT $<0.9$; BS $<75 \%$; $\mathrm{SH}$-aLRT $<0.85$ ); significant support values are in bold face (aBAYES $\geq 0.95$; aLRT $\geq 0.9$; BS $\geq 75 \%$; SH-aLRT $\geq 0.85$ ). Colors were used when support is significant for at least 3 out of 4 methods and fine black lines for those with low support (two or fewer significant values). The bars above branches indicate clades found in the topology obtained from the Leptothecata 16S18S28S matrix; bars beneath the branches indicate the same for 16S18S28S_Nrw4. To the right of the description of major clades are details on the newly proposed groups, emphasizing suborders and orders (black box). Purple dots indicate unstable terminals (rogue taxa) and yellow dots were likely misidentified. Rogue taxa were not considered in the evaluation of the clades in other analyses, and together with the ones marked by yellow dots, are considered incertae sedis in the proposed taxonomy. Basic taxonomy (species and genera) from the WoRMS database.

Statocysta and Lineage 2. The working hypothesis (Fig. 1) strongly supports Statocysta and Macrocolonia $^{45}$. Statocysta comprises the majority of species with medusae in the life cycle (Figs 1-3; Table 2) and is composed by three large clades: Campanulinida sensu novum, Eirenida taxon novum (divided into two subclades) and Proboscoida sensu novum (also comprising two subclades). Species of Lineage 2, encompassing species of Hebellidae (Hebella scandens, Hebella venusta and Anthohebella parasitica; non monophyletic) and Laodiceidae (S. gotoi), have stable position and high support as a sister group of the clade formed by Hydrodendron gardineri (R 1) + Statocysta (including Opercularella lacerata -R 2-). Even though H. gardineri and Opercularella operculata were identified as rogue taxa, and classified accordingly in our working hypothesis (R 1 and R 2, respectively; Fig. 1), bootstrap was the only non-significant measure for $H$. gardineri position, out of the 4 branch support methods employed. Nevertheless, the position of this lineage varies widely across topologies. It 

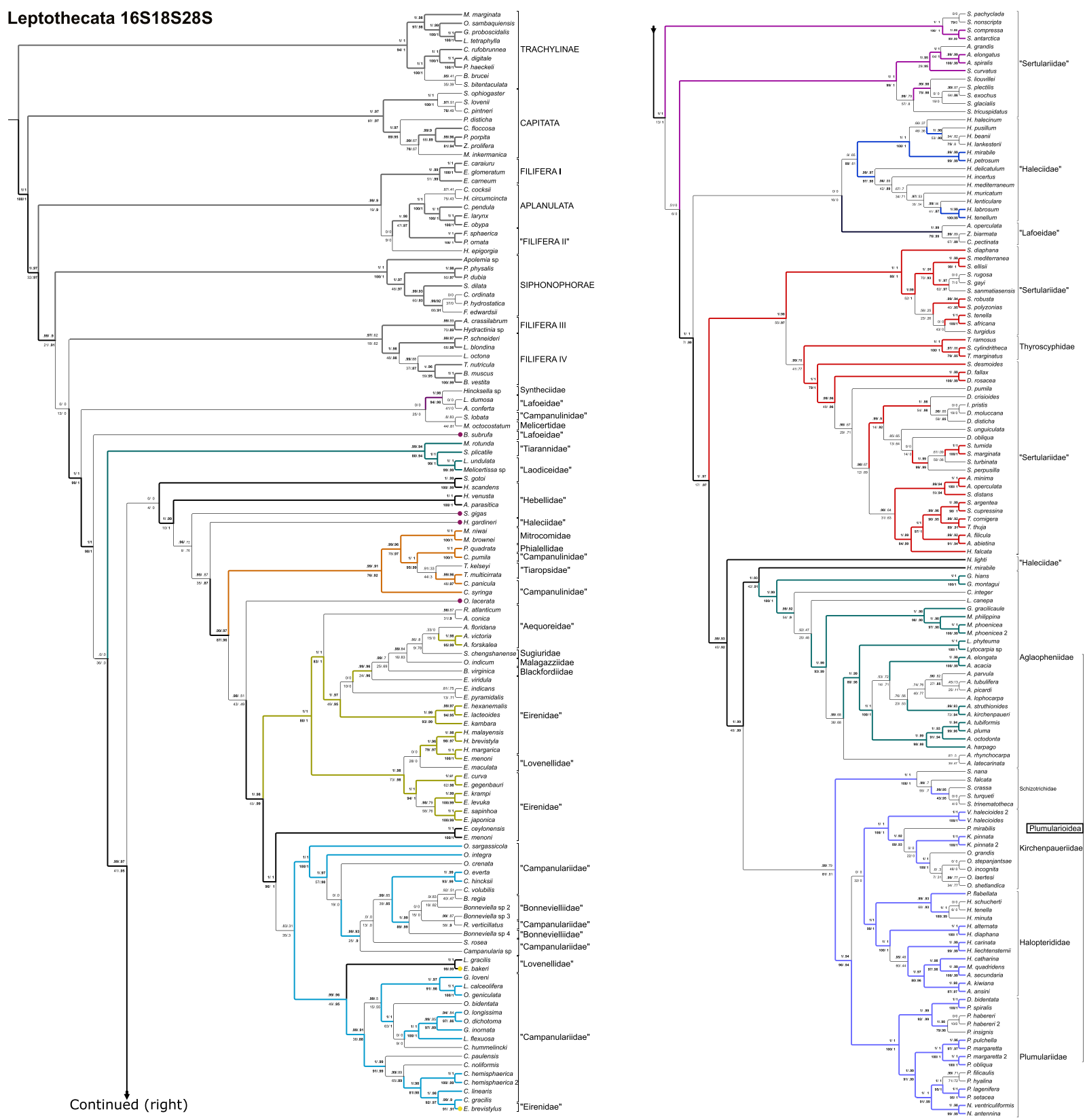

Figure 2. Cladogram of the Leptothecata obtained from the unfiltered (matrix 16S18S28S). Branch colors, support values and notation for unstable taxa as described in Fig. 1. Names within quotation marks (" ”) are non-monophyletic groups (traditional taxonomy from WoRMS).

is recovered as the sister group of Campanulinida sensu novum in the topology obtained from the unfiltered data (16S18S28S - Fig. 2) and as sister of its congeneric species in the 16S18S28S_Nrw4 analysis (Fig. 3).

The Campanulinida sensu novum (Fig. 1) includes species of Campanulinidae (Calycella syringa, Campanulina panicula and Campanulina pumila), Phialellidae (Phialella quadrata), and Mitrocomidae, the only family that is resolved as monophyletic (Mitrocomella brownei, Mitrocomella niwai and Tiaropsidium kelseyi). Campanulinida sensu novum is retrieved as sister group of Eirenida taxon novum + Proboscoida sensu novum in the working hypothesis (Fig. 1).

Two clades within Eirenida taxon novum are highly supported in all results. Eirenids I comprises species of Aequoreidae (Rhacostoma atlanticum and Aequorea spp.), Eirenidae (Eutonina indicans, and Eirene spp.), Octophialucium indicum (the only species assigned to Malagazzidae in our analysis), Blackfordiidae (Blackfordia virginica), and Sugiuridae (Sugiura chengshanense) (Figs 1-3). Eirenids II comprises genera from two lineages with high support: one group includes species of Eirenidae (Helgicirrha brevistyla, Helgicirrha malayensis) and species of Lovenellidae (Hydranthea margarica, Eucheilota maculata and Eucheilota menoni); the sister lineage comprises species of Eutima and Eugymnanthea japonica. 


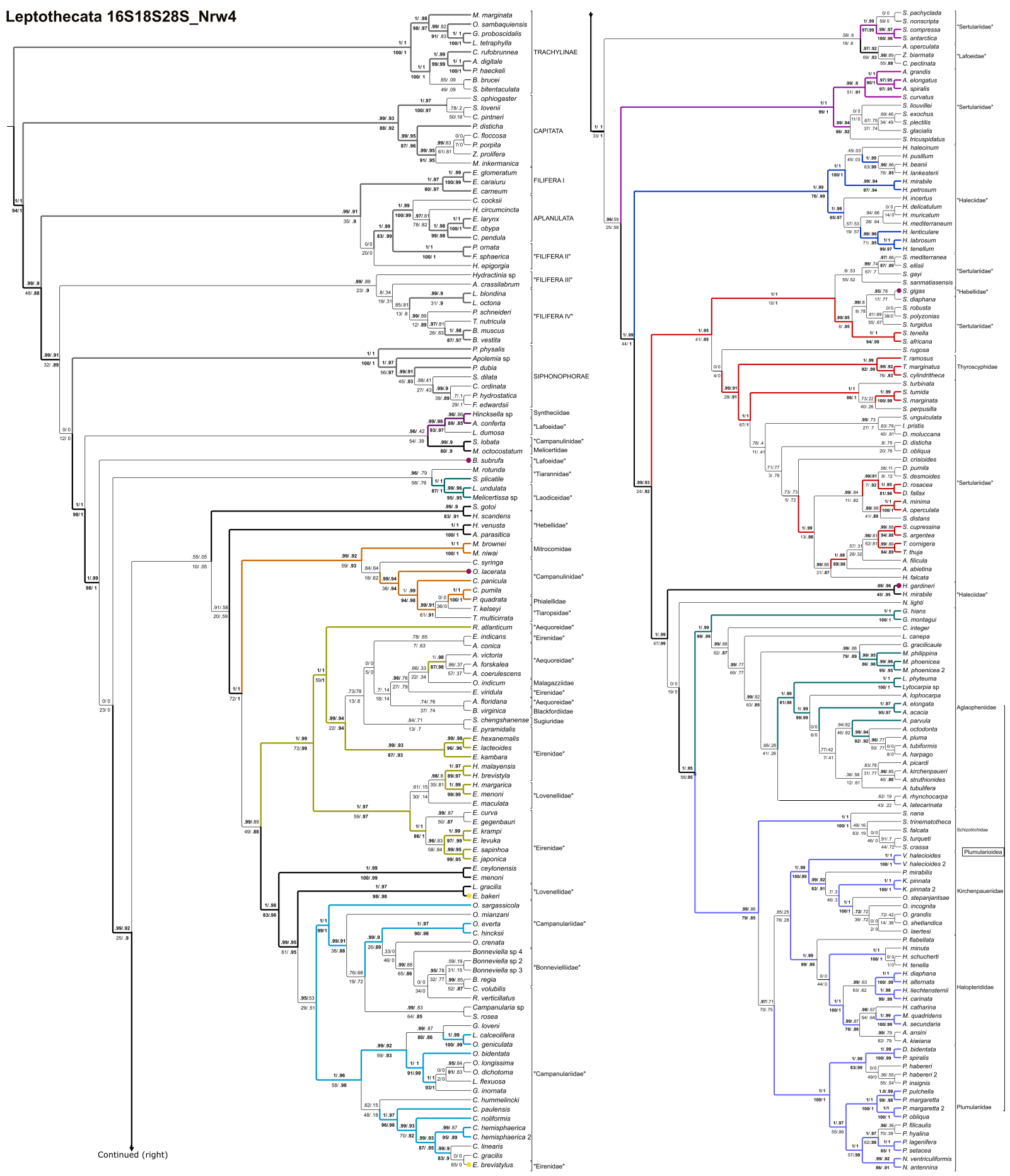

Figure 3. Cladogram of the Leptothecata obtained from the intensively filtered (matrix 16S18S28S_Nrw4). Branch colors, support values and notation for unstable taxa and taxonomy as described in Fig. 1.

The last clade of Statocysta is Proboscoida sensu novum. It includes species of Campanulariidae and Bonneviellidae, together with species from the Lineage 3 (Eirene ceylonensis and Eirene menoni, and the Lovenellidae Eucheilota bakeri and Lovenella gracilis). Given the high nodal support of the two main clades of Proboscoida sensu novum, we propose two new taxa: Campanulariida sensu novum (composed by the sampled species of Orthopyxis, Campanularia, Bonneviella, plus Rhizocaulus verticillatus and Silicularia rosea), and Obeliida taxon novum, composed by Obeliidae sensu novum (species of Laomedea and Obelia, both genera recovered as polyphyletic in our results) and Clytiidae sensu novum (species of Clytia and Eirene brevistylus, possibly misidentified, which together with Lineage 3 are considered Statocysta incertae sedis). 


\begin{tabular}{|c|c|c|c|c|c|c|}
\hline Analysis & $16 S 18 S 28 S$ & 16S18S28S_N & $\begin{array}{l}\text { 16S18S28S } \\
\text { Nrw4 }\end{array}$ & $16 S$ & 16S_N & 16_Nrw4 \\
\hline Terminal taxa & 263 & 263 & 263 & 254 & 254 & 254 \\
\hline Total sites & 6,254 & 5,608 & 4,548 & 647 & 582 & 452 \\
\hline Conserved sites & 2,522 & 2,463 & 2,413 & 118 & 117 & 112 \\
\hline Variable sites & 3,677 & 3,131 & 2,132 & 526 & 465 & 340 \\
\hline Informative sites (parsimony) & 2,861 & 2,478 & 1,551 & 462 & 417 & 300 \\
\hline Singleton sites & 757 & 637 & 581 & 61 & 46 & 40 \\
\hline Gaps and missing data (\%) & 38.55 & 33.02 & 28.94 & 15.97 & 8.72 & 3.64 \\
\hline $\begin{array}{l}\text { Maintained sites (Aliscore, } \\
\text { in \%) }\end{array}$ & & 89.67 & 72.72 & & 89.95 & 69.86 \\
\hline Log-likelihood (RAxML) & -169046.88 & -151027.90 & -71717.62 & -39040.32 & -36397.24 & -19898.97 \\
\hline \multirow{2}{*}{ Freq A C G T (PhyML) } & 0.280 .19 & 0.280 .19 & 0.290 .19 & 0.400 .12 & 0.400 .12 & 0.380 .13 \\
\hline & 0.260 .26 & 0.260 .25 & 0.260 .25 & 0.150 .31 & 0.150 .31 & 0.170 .30 \\
\hline $\begin{array}{l}\text { Invariant proportion: MEGA } \\
(\text { Gamma + I. “use all sites") }\end{array}$ & $\sim 36 \%$ & $\sim 39 \%$ & $\sim 43 \%$ & $\sim 16 \%$ & $\sim 18 \%$ & $\sim 21 \%$ \\
\hline $\begin{array}{l}\text { Parameters: (alpha PhyML) } \\
\text { [Gamma MEGA] }\end{array}$ & $(0.344)[0.647]$ & $(0.325)[0.651]$ & $(0.294)[0.548]$ & $(0.424)[0.587]$ & $(0.425)[0.571]$ & $(0.6361)[0.443]$ \\
\hline Analysis & $18 S$ & 18S_N & $18 \mathrm{~S}$ Nrw4 & $28 S$ & $28 \mathrm{~S} \mathrm{~N}$ & 28S Nrw4 \\
\hline Terminal taxa & 207 & 207 & 207 & 181 & 181 & 181 \\
\hline Total sites & 1,955 & 1,802 & 1,566 & 3,652 & 3,224 & 2,530 \\
\hline Conserved sites & 888 & 862 & 848 & 1,516 & 1,484 & 1,453 \\
\hline Variable sites & 1,050 & 940 & 718 & 2,101 & 1,726 & 1,074 \\
\hline Informative sites (parsimony) & 782 & 708 & 506 & 1.617 & 1.353 & 745 \\
\hline Singleton sites & 262 & 229 & 212 & 434 & 362 & 329 \\
\hline Gaps and missing data (\%) & 14.40 & 7.93 & 2.86 & 20.39 & 12.67 & 7.31 \\
\hline $\begin{array}{l}\text { Maintained sites (Aliscore, } \\
\text { in \%) }\end{array}$ & & 92.17 & 80.10 & & 88.28 & 69.28 \\
\hline Log-likelihood (RAxML) & -37348.89 & -35029.30 & -21383.44 & -91649.78 & -78681.31 & -29528.53 \\
\hline \multirow{2}{*}{ Freq A C G T (PhyML) } & 0.260 .19 & 0.260 .19 & 0.270 .19 & 0.260 .21 & 0.260 .21 & 0.270 .20 \\
\hline & 0.260 .26 & 0.260 .26 & 0.260 .26 & 0.280 .24 & 0.280 .23 & 0.270 .23 \\
\hline $\begin{array}{l}\text { Invariant proportion: MEGA } \\
\text { (Gamma+I; "use all sites") }\end{array}$ & $\sim 38 \%$ & $\sim 40 \%$ & $\sim 42 \%$ & $\sim 38 \%$ & $\sim 42 \%$ & $\sim 44 \%$ \\
\hline $\begin{array}{l}\text { Parameters: (alpha PhyML) } \\
\text { [Gamma MEGA] }\end{array}$ & $(0.296)[0.601]$ & $(0.296)[0.595]$ & $(0.273)[0.561]$ & $(0.319)[0.633]$ & $(0.295)[0.643]$ & $(0.247)[0.530]$ \\
\hline
\end{tabular}

Table 1. Summary statistics for the data matrices corresponding maximum likelihood trees. (multilocus: 16S1828S, 16S18S28S_N, 16S18S28S_Nrw4, single locus: 16S, 16S_N, 16S_Nrw4, 18S, 18S_N, 18S_Nrw4, 28S, 28S_N, 28S_Nrw4). The log-likelihoods were calculated in RAxML under the GTR+GAMMA model. Nucleotide frequencies and proportion of invariant sites calculated in PhyML and MEGA (together with the estimate of the alpha and gamma parameters in both programs). Cells were left empty when non-applicable.

Macrocolonia. This taxon is divided into four large crown clades (Staurothecida taxon novum, Haleciida sensu novum, Sertulariida taxon novum and Plumupheniida taxon novum; Figs. 1 and 4) and several apical taxa (e.g., Aglaopheniida taxon novum, Plumulariida sensu novum, Staurothecidae fam. nov., Symplectoscyphidae fam. nov.), and a clade with unstable position within Macrocolonia, named Lineage 4 ("Zygophylacinae"43,44). Even though monophyly of L 4 is highly supported, its position as sister group of the Sertulariida has virtually no support (Fig. 1) and neither has the L $4+$ Haleciidae clade recovered in the analysis of the unfiltered matrix (Fig. 2). It was placed as the sister group of the Sertulariidae in the tree obtained from the highly-filtered dataset (Fig. 3), but again, support was non-significant regardless of the method employed. Lineage 5 (Nemalecium lighti and Hydrodendron mirabile) is part of Plumuphenniida and the rogue taxon $\mathrm{R} 4$, Scandia gigas, within Sertulariidae (Figs 1-3; Table 2). Billardia subrufa (R 5) was recovered either as sister taxon of Macrocolonia (Fig. 1) or close to Lafoeida sensu novum + Lineage 1 (Figs 2 and 3). The placement of this taxon was weakly supported in all analyses.

Macrocolonia subgroups require redefinition; therefore we propose some amendments and new taxa:

- Staurothecidae fam. nov. (Type genus: Staurotheca Allman, 1888), with high nodal support, includes species of Staurotheca, for which only Staurotheca antarctica had nuclear markers included in the analyses; we acknowledge that Staurotheca dichotoma Allman, 1888, type-species of Staurotheca, is missing from our analysis. However, the hypothesis seems reasonable because of the wide taxon sampling of congeners and the taxonomic stability of the genus. More data on the type species should further test the present hypothesis.

- Symplectoscyphidae fam. nov. (Type genus: Symplectoscyphus Marktanner-Turneretscher, 1890) includes Antarctoscyphus Peña Cantero, García Carrascosa \& Vervoort, 1997 and Symplectoscyphus, two monophyletic genera with high support. An exception is Symplectoscyphus curvatus, which is sister group of the Antarctoscyphus species (Figs 1-3; see considerations about taxonomic validation of $S$. curvatus in the discussion section); we acknowledge that Symplectoscyphus australis Marktanner-Turneretscher, 1890, type-species of Symplectoscyphus, 


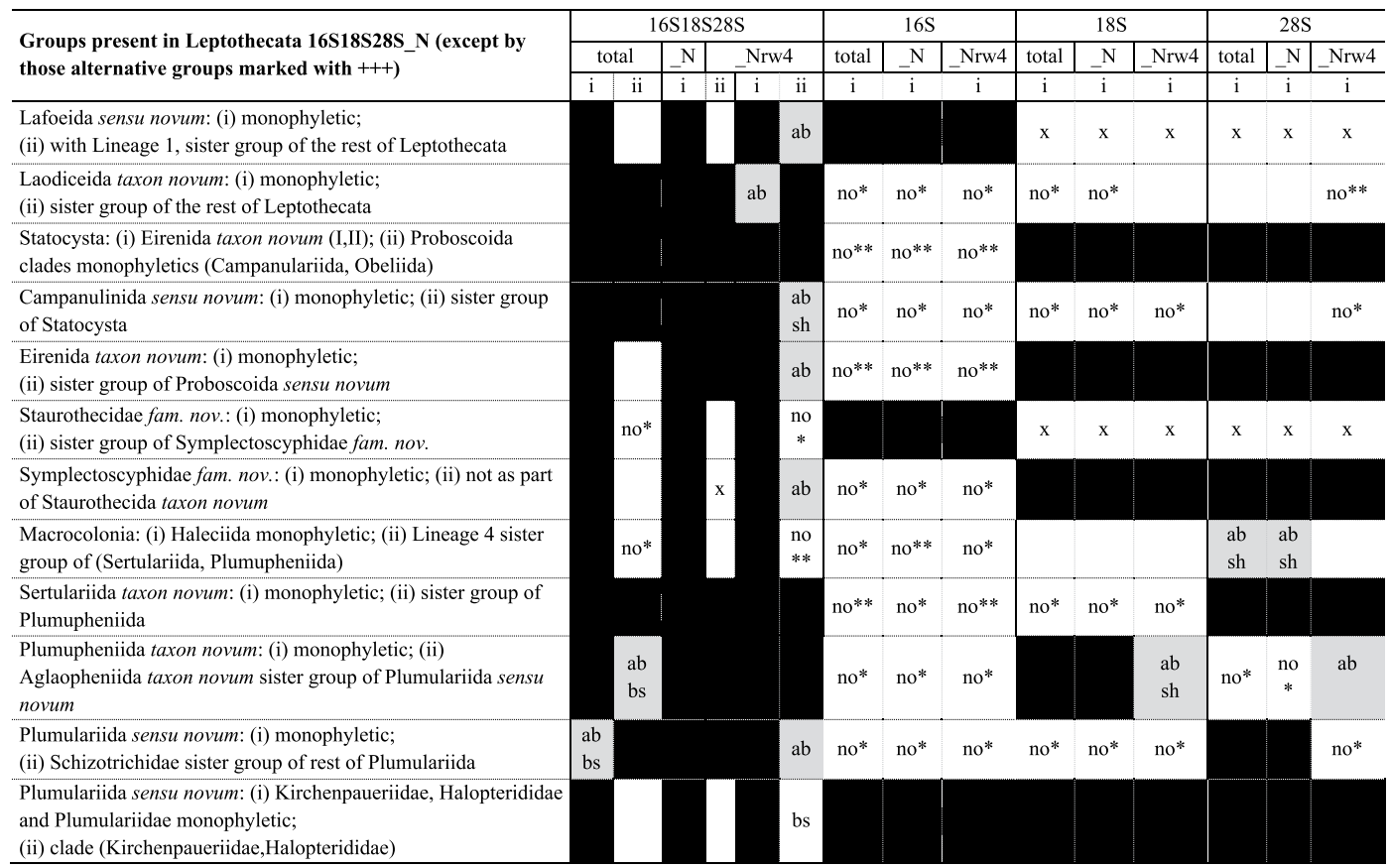

Table 2. Results of nodal support for the main groups of Leptothecata in 16S18S28S_N (Fig. 1) and all topologies. Black cells indicate nodes significantly supported by at least 3 of 4 support methods for multilocus, and 3 of 3 for single locus analysis; gray cells indicate that one or two branch support methods are significant $\left(\mathrm{ab}=\mathrm{aBAYES}\right.$; $\mathrm{sh}=\mathrm{SH} \_\mathrm{aLRT}$, bs $=$ Bootstrap); white cells represent unsupported clades considering all methods. Single asterisk $\left({ }^{\star}\right)$ indicates para- or polyphyletic taxa, with small patristic distances among terminals; double asterisks ${ }^{* *}$ ) indicate large patristic distances (see figures and text for details). Symbol $\mathrm{x}$ indicates non-applicable (see main text and Supplementary Table S1 online). Rogue taxa and lineages with unstable placements are not considered, except where detailed.

is missing from our analysis; however the hypothesis is reasonable because of the wide taxon sampling of congeners and the taxonomic stability of the genus. Future data on the type species will test accordingly the present hypothesis.

- Haleciida sensu novum, including species of Halecium Oken, 1815, is highly supported and occupies a stable position as sister group of the clade (Sertulariida taxon novum (Aglaopheniida taxon novum, Plumulariida sensu novum)) in the multilocus analyses.

- Sertulariida taxon novum, composed by Sertularellidae fam. nov. (Type genus: Sertularella Gray, 1848; includes S. polyzonias (Linnaeus, 1758), type species of Sertularella, besides its congeners and Symplectoscyphus turgidus), Thyroscyphidae (including species of Thyroscyphus Allman, 1877 and Sertularelloides cylindritheca), and Sertulariidae (including Idiellana pristis, Hydrallmania falcata, Salacia desmoides and species of the monophyletic genera Abietinaria Kirchenpauer, 1884, Amphisbetia L. Agassiz, 1862, Diphasia L. Agassiz, 1862 and Thuiaria Fleming, 1828, as well as the species of the non-monophyletic genera Dynamena Lamouroux, 1812 and Sertularia Linnaeus, 1758).

Although $N$. lighti and H. mirabile are traditionally placed into Haleciidae Hincks, 1868, they are a basal lineage (Lineage 5) of the well-supported clade Plumupheniida taxon novum (Figs 1 and 3), which includes two main taxa:

- Aglaopheniida taxon novum, a well-supported node in all combined analyses (Figs 1-3; Table 2);

- Plumulariida sensu novum, composed by Schizotrichidae Peña Cantero, Sentandreu \& Latorre, 2010 (for which the phylogenetic position is kept in multilocus analysis), Kirchenpaueriidae Stechow, 1921, Halopterididae Millard, 1962 (in which none of the traditional genera, as Antennella Allman, 1877 and Halopteris Allman, 1877, are monophyletic in the combined analyses), and Plumulariidae McCrady, 1859 (in which only Nemertesia Lamouroux, 1812 is monophyletic).

\section{Discussion}

In this section we contrast the new taxonomic classification proposed herein with the traditional one (Figs 1-4; Tables 2-4 and Supplementary Table S1; number of species for each group based on WoRMS database ${ }^{2}$ ), and discuss some macroevolutionary patterns that may be associated with the diversification of Leptothecata.

Molecular markers and evaluation of phylogenetic results. The general outline of our results is consistent with recent hypotheses ${ }^{41,45,46}$, but some particular aspects should be emphasized. The mitochondrial marker $16 \mathrm{~S}$ accumulates greater nucleotide variation than the nuclear markers $18 \mathrm{~S}$ and 28S, which may be seen by the differences in conserved sites, singletons and informative sites for parsimony, in relation to the total sequence size (Table 1). The 16S sequences are shorter and display a relatively greater proportion of filtered sites than $18 \mathrm{~S}$ and $28 \mathrm{~S}$ (Table 1). Thus, average support in $16 \mathrm{~S}$ trees is expected to be lower for non-parametric methods, especially in the case of bootstrap. 


\begin{tabular}{|c|c|c|c|c|c|c|}
\hline Group & Code & Mono $(\mathrm{Y} / \mathrm{N})$ ? & Bouillon 1995 & WoRMS 2015 & Cornelius $^{4,5}$ & $\mathbf{P} / \mathbf{M}$ \\
\hline LEPTOTHECATA & & $\mathbf{Y}$ & $\begin{array}{l}\text { Subclass; Fleming, } 1828 \\
\text { (=Thecatae) }\end{array}$ & Order; Cornelius, 1992 & $\begin{array}{l}\text { Subclass; Cornelius, } \\
\text { 1992(=Leptothecatae) }\end{array}$ & $\mathrm{P} / \mathrm{M}$ \\
\hline PROBOSCOIDA & $\mathrm{P}$ & $\mathrm{N}$ & Order; Broch, 1909 & $\begin{array}{l}\text { Suborder; Broch, } 1910 \text { (not } \\
\text { accepted: "polyphyletic } \\
\text { assemblage") }\end{array}$ & Order; Broch, 1910 & \multirow{3}{*}{$\mathrm{P}$} \\
\hline Campanulariida & $\mathrm{P}$ & $\mathrm{N}$ & Suborder; Johnston, 1836 & absent & Suborder; Bouillon 1984 & \\
\hline Campanularioidea & $\mathrm{P}$ & $\mathrm{N}$ & Johnston, 1836 & absent & Johnston, 1837 & \\
\hline Phialuciidae + Campanulariidae & P_1 & $\mathrm{X}$ & absent & absent & absent & $\mathrm{P}$ \\
\hline Phialuciidae & P_1.1 & NS & Kramp, 1955 & $=$ & $=$ & M \\
\hline Campanulariidae & P_1.2 & $\mathrm{N}$ & Johnston, $\mathbf{1 8 3 6}$ & $=$ & Johnston, $\mathbf{1 8 3 7}$ & $\mathrm{M}$ \\
\hline Bonneviellidae & P_2 & $\mathrm{N}$ & Broch, 1909 & $=$ & Order; Broch, 1910 & $\mathrm{P}$ \\
\hline CONICA & $\mathrm{C}$ & $\mathrm{N}$ & Order; Broch, 1909 & $\begin{array}{l}\text { Genus; Broch, } 1910 \text { (not accept- } \\
\text { ed: "polyphyletic assemblage") }\end{array}$ & Order; Broch, 1910 & $\mathrm{P}$ \\
\hline Campanulinida + Lafoeida & $\mathrm{Ce} \_1$ & $\mathrm{~N}$ & absent & absent & absent & $\mathrm{P}$ \\
\hline Lafoeida & C_1 & $\mathrm{N}$ & Suborder; Agassiz, 1865 & absent & Suborder; Bouillon 1984 & \multirow{2}{*}{$\mathrm{P}$} \\
\hline Lafoeoidea & C_1 & $\mathrm{N}$ & Agassiz, 1865 & absent & $=$ & \\
\hline Clathrozoidae & C_1.1 & NS & Stechow, 1921 & $=$ & $=$ & $\mathrm{P}$ \\
\hline Hebellidae & C_1 $1.2^{* *}$ & $\mathrm{~N}$ & absent (part of Lafoeidae) & Fraser, 1912 & $=$ & $\mathrm{P} / \mathrm{M}$ \\
\hline Lafoeidae & C_1.3 & $\mathrm{N}$ & Agassiz, 1865 & Hincks, 1868 & $=$ & $\mathrm{P}$ \\
\hline Campanulinida & C_2 & $\mathrm{N}$ & Suborder; Hincks, 1868 & absent & Suborder; Bouillon, 1984 & $\mathrm{P}$ \\
\hline Campanulinoidea & $\begin{array}{l}\text { C_3 \& } \\
\text { C_11 } \\
\end{array}$ & $\mathrm{N}$ & Hincks, 1868 & absent & $=$ & $* *$ \\
\hline Campanulinidae & C_3 & $\mathrm{N}$ & Hincks, 1868 & $=$ & $=$ & $\mathrm{M}$ \\
\hline Campanulinida - Campanulinidae & C_4 & $\mathrm{N}$ & absent & absent & absent & $\mathrm{M}$ \\
\hline Laodiceoidea & C_5 & $\mathbf{Y}^{*}$ & Browne, 1907 & absent & Agassiz, 1862 & $\mathrm{M}$ \\
\hline Laodiceidae & C_5.1 & $\mathbf{Y}^{*}$ & Browne, 1907 & Agassiz, 1862 & $=$ WoRMS & $\mathrm{P} / \mathrm{M}$ \\
\hline Tiarannidae & C_5.2 & $\mathrm{N}$ & Russell, 1940 & Russell, 1950 & $=$ & $\mathrm{P} / \mathrm{M}$ \\
\hline $\begin{array}{l}\text { Dipleurosomatoidea }+ \\
\text { Mitrocomoidea + Lovenelloidea }+ \\
\text { Eirenoidea + Campanulinoidea }\end{array}$ & C_6 & $\mathrm{N}$ & absent & absent & absent & M \\
\hline Dipleurosomatoidea & C_7 & $\mathrm{X}$ & Boeck, 1866 & absent & $=$ & M \\
\hline Orchistomatidae & C_7.1 & NS & $\begin{array}{c}\text { Bouillon, } 1984 \\
\text { (=Orchistomidae) }\end{array}$ & $\begin{array}{l}=(\text { Orchistomidae: "incorrect } \\
\text { formation of family name" })\end{array}$ & $\begin{array}{l}\text { Bouillon, } 1984 \text { (recognized as } \\
\text { "Orchistomidae") }\end{array}$ & M \\
\hline Dipleurosomatidae & C_7.2 & NS & Boeck, 1866 & Russell, 1953 & $=$ & $\mathrm{P} / \mathrm{M}$ \\
\hline Melicertidae & C_7.3 & $\mathrm{X}$ & Agassiz, 1862 & $=$ & $=$ & $\mathrm{P} / \mathrm{M}$ \\
\hline $\begin{array}{l}\text { Mitrocomoidea + Lovenelloidea + } \\
\text { Eirenoidea + Campanulinoidea }\end{array}$ & C_8 & $\mathrm{N}$ & absent & absent & absent & M \\
\hline Mitrocomoidea & C_9 & $\mathrm{N}$ & Torrey, 1909 & absent & Haeckel, 1879 & \multirow{2}{*}{$\mathrm{M}$} \\
\hline Mitrocomidae & $=$ C_9 & $\mathrm{N}$ & Torrey, 1909 & Haeckel, 1879 & $=$ WoRMS & \\
\hline $\begin{array}{l}\text { Lovenelloidea + Eirenoidea + } \\
\text { Campanulinoidea }^{*}\end{array}$ & C_10 & $\mathrm{N}$ & absent & absent & absent & M \\
\hline $\begin{array}{l}\text { Campanulinoidea* }^{*} \\
\text { (= Campanulinoidea - } \\
\text { Campanulinidae) }\end{array}$ & C_11 & $\mathrm{N}$ & absent & absent & absent & M \\
\hline Malagazziidae + Aequoreidae & C_12 & $\mathrm{N}$ & absent & absent & absent & $\mathrm{M}$ \\
\hline Malagazziidae & C_12.1 & $\mathrm{X}$ & Bouillon, 1984 & $=$ & $=$ & $\mathrm{M}$ \\
\hline Aequoreidae & C_12.2 & $\mathrm{N}$ & Eschscholtz, 1829 & $=$ & $=$ & M \\
\hline Blackfordiidae + Phialellidae + Sugiuridae & C_13 & $\mathrm{N}$ & absent & absent & absent & $\mathrm{M}$ \\
\hline Blackfordiidae & C_13.1 & $\mathrm{X}$ & Bouillon, 1984 & $=$ & not sampled & $\mathrm{P} / \mathrm{M}$ \\
\hline Phialellidae & C_13.2 & $\mathrm{X}$ & Russell, 1953 & $=$ & $=$ & $\mathrm{P} / \mathrm{M}$ \\
\hline Sugiuridae & C_13.3 & $\mathrm{X}$ & Bouillon, 1984 & $=$ & not sampled & $\mathrm{P} / \mathrm{M}$ \\
\hline Lovenelloidea + Eirenoidea & C_14 & $\mathrm{N}$ & absent & absent & absent & $\mathrm{M}$ \\
\hline Lovenelloidea & C_15 & $\mathrm{N}$ & Russell, 1953 & absent & $=$ & M \\
\hline Cirrholoveniidae & C_15.1 & NS & Bouillon, 1984 & $=$ & $=$ & $\mathrm{P}$ \\
\hline Lovenellidae & C_15.2 & $\mathrm{N}$ & Russell, 1953 & $=$ & $=$ & $\mathrm{P}$ \\
\hline Eucheilotidae & C_15.3 & $\mathrm{N}$ & Picard, 1958 & $\begin{array}{l}\text { not accepted (synonymous of } \\
\text { Lovenellidae) }\end{array}$ & Bouillon, 1984 & $\mathrm{P}$ \\
\hline Eirenoidea & C_16 & $\mathrm{N}$ & Haeckel, 1879 & absent & $=$ & \multirow{2}{*}{$M$} \\
\hline Eirenidae & C_16 & $\mathrm{N}$ & Haeckel, 1879** & $=$ & $=$ & \\
\hline Haleciida + Plumulariida & Ce 2 & $\mathrm{~N}$ & absent & absent & absent & $\mathrm{P}$ \\
\hline Haleciida & $\mathrm{Ce} \_3$ & $\mathrm{~N}$ & Suborder; Hincks, 1868 & absent & Suborder; Bouillon, 1984 & $\mathrm{P}$ \\
\hline
\end{tabular}




\begin{tabular}{|c|c|c|c|c|c|c|}
\hline Group & Code & $\operatorname{Mono}(\mathrm{Y} / \mathrm{N}) ?$ & Bouillon 1995 & WoRMS 2015 & Cornelius ${ }^{4,5}$ & $\mathbf{P} / \mathbf{M}$ \\
\hline Halecioidea & Ce_3 & $\mathrm{N}$ & Hincks, 1868 & absent & $=$ & \multirow{3}{*}{$\mathrm{P}$} \\
\hline Haleciidae & Ce_3 & $\mathrm{N}$ & Hincks, 1868 & $=$ & $=$ & \\
\hline Plumulariida & $\mathrm{Ce} \_4^{* *}$ & $\mathrm{~N}$ & Hincks, 1868 & absent & Suborder; Bouillon, 1984 & \\
\hline Sertularioidea & $\mathrm{Ce} \_5^{* *}$ & $\mathrm{~N}$ & Lamouroux, 1812 & absent & $=$ & $\mathrm{P}$ \\
\hline Sertulariidae & Ce_5.1 & $\mathrm{N}$ & Lamouroux, 1812 & $=$ & $=$ & $\mathrm{P}$ \\
\hline Syntheciidae & Ce_5.2 & $\mathrm{x}$ & $\begin{array}{c}\text { Marktanner-Turneretscher, } \\
1890\end{array}$ & $=$ & $=$ & $\mathrm{P}$ \\
\hline Plumularioidea & Ce_6 & $\mathrm{Y}$ & Hincks, 1868 & McCrady, 1859 $9^{* * *}$ & Agassiz, 1862 & $\mathrm{P}$ \\
\hline Aglaopheniidae & Ce_6.1 & $\mathbf{Y}$ & Broch, 1918 & Marktanner-Turneretscher, $\mathbf{1 8 9 0}$ & Agassiz, 1862 & $\mathrm{P}$ \\
\hline Kirchenpaueriidae & Ce_6.2 & $\mathbf{Y}$ & Millard 1962 & $\begin{array}{c}\text { Stechow, 1921; Marktanner-Tur- } \\
\text { neretscher, } \mathbf{1 8 9 0}^{* \star \star}\end{array}$ & $\begin{array}{l}\text { Considered Subfamily } \\
\text { Kirchenpaueriinae Stechow, } \\
1921 \text { (in Plumulariidae) }\end{array}$ & $\mathrm{P}$ \\
\hline Halopterididae & Ce_6.3 & $\mathrm{N}$ & Millard, 1962 & $=$ & $\begin{array}{l}{ }^{* *} \text { Considered Subfamily Halop- } \\
\text { teriinae Millard, 1962 } \\
\text { (in Plumulariidae) } \\
\end{array}$ & $\mathrm{P}$ \\
\hline Plumulariidae & Ce_6.4 & $\mathbf{Y}$ & Hincks, 1868 & $\begin{array}{c}\text { Agassiz, 1862; McCrady, } \\
1859^{* * *}\end{array}$ & Agassiz, $\mathbf{1 8 6 2}^{\star \star}$ & $\mathrm{P}$ \\
\hline
\end{tabular}

Table 3. Taxonomic proposal for Leptothecata compared to Bouillon ${ }^{28}$ Cornelius $^{4,5}$ and the WoRMS database $^{2}$. The column "Mono" reports whether the corresponding group is monophyletic according to our working hypothesis. Asterisks indicate monophyly but for one terminal, $\mathrm{X}$ indicate that only one representative terminal of the group was sampled (therefore we are unable to fully ascertain the phylogenetic status of the group in our analysis) and NS indicates that no representative of the group was sampled. Taxonomic status and authorship according to the sources above are listed under respective columns. The symbol $(=)$ indicates that taxonomy and authorship are identical to Bouillon ${ }^{28}$. Groups proposed in XIX century are in boldface. "P/M" indicates if original proposal was mainly based on polyp $(\mathrm{P})$, medusae $(\mathrm{M})$ characters or both $(\mathrm{P} / \mathrm{M})$. New taxonomic proposal and differences from Bouillon ${ }^{28}$ and WoRMS ${ }^{2}$ are also presented in Fig. 4, Table 4 and Table S1. ${ }^{* *}$ differences in the contents considering original proposal from Bouillon ${ }^{28} \cdot{ }^{* *}=$ considering Calder ${ }^{107}$.

Rogue taxa and "Lineages" found in the analysis of the 16S matrix have lower nodal support and greater tendency to change their phylogenetic position according to the level of filtering applied to the concatenated matrices. This is especially true for terminals with abundant missing data, such as H. gardineri and S. gigas (Figs 1-3; Supplementary Information, "Rogue taxa analysis" section). Taxonomic artifacts associated with 16S include long-branch attraction (LBA, also see Peña Cantero et al. ${ }^{46}$ ), such as between Siphonophorae and Plumularioidea, the group with the greatest variation in ribosomal data in Leptothecata (see Supplementary Figs S3-5 online). Previous studies attempted to get around this issue by not including Siphonophorae species as part of outgroup sampling ${ }^{41}$. Assuming a somewhat constant evolutionary rate, it is expected that basal lineages are more variable with greater saturation. While the use of $16 \mathrm{~S}$ recovered most of the lineages of Plumularioidea, the LBA artifact results in the accumulation of nucleotide variation, causing non-historical convergence of Siphonophorae and Plumularioidea, which are groups with substantial differences in their life cycles, such as the loss of the medusa stage, strong polymorphism and colony specialization. Interestingly, these taxa bear superficial resemblance, such as the lack of the medusa stage, strong polymorphism and high zooid specialization.

Most non-Plumularioidea lineages are not monophyletic in the $16 \mathrm{~S}$ analysis, in contrast with patterns from the nuclear markers $18 \mathrm{~S}$ and $28 \mathrm{~S}$, both of which result in similar phylogenies, with $18 \mathrm{~S}$ having lower resolution (Figs S6-8). The $28 \mathrm{~S}$ provides a robust phylogenetic framework for Leptothecata due to the number of variable nucleotides, relative gene frequencies in the different matrices (with and without filtering) and support values in the individual phylogenies. Basal nodes in the $28 \mathrm{~S}$ phylogeny and other phylogenetic groups (e.g., Sertulariida taxon novum) are recovered in the concatenated data matrices, with higher support when compared with nodal support of single-gene phylogenies.

Analyses of data matrices assembled under a range of criteria (combined or individual markers and filtering taxa and/or nucleotides at different levels) and employing different branch support methods, allow a better evaluation of the nodal stability by assessing congruence among results (e.g., Table 2; Supplementary Information "Rogue taxa analysis" online). Topologies change with the level of filtering, usually with a concomitant decrease in nodal support. This indicates that the highest filtering level "throws the baby out with the bath water", i.e. eliminates information together with spurious phylogenetic signal. Intermediate levels of filtering seemingly strike a more reasonable signal-to-noise ratio. Additionally, simulations strongly indicate that non-parametric bootstrap is the branch support method most prone to type II error (i.e. failing to support a "true" clade) ${ }^{48}$. Therefore, by employing alternative support methods, our working hypothesis has recovered a greater number of significantly supported clades than what would be obtained by employing traditional bootstrapping (see Methods for details). All the taxonomic propositions in the following sections were thus based on this hypothesis (Fig. 1).

Outgroups and sister groups of Leptothecata. The sister group of Leptothecata remains unclear ${ }^{35,45}$, with different taxa being included or excluded in previous analyses of Leptothecata (e.g., exclusion of Siphonophorae $\left.{ }^{41}\right)$. Our topologies resulting from combined matrices, did not recover a well-supported sister group for Leptothecata. The only high nodal support for a sister group of Leptothecata was found in the $28 \mathrm{~S}$ marker analyses (28S_N and 28_Nrw4), in which Bougainvilliidae (Filifera IV after Cartwright et al. ${ }^{35}$ ) is 
well-supported as its sister group (basal relationships similar to 16S18S28S). However, more data are definitely necessary to confirm the placement of this family.

Previous conflicts in leptothecate phylogeny and a new working hypothesis. Molecular studies based on ever-increasing number of species have contradicted taxa considered to be monophyletic under a traditional sense, such as Conica, Proboscoida and Plumulariida ${ }^{45,49}$. However, our results also corroborate some traditional taxa defined by their exoskeleton and specialized characters of polyps, as in the reformulated Plumularioidea (Fig. 4, Table 2). Ours is the most inclusive analysis of Leptothecata to date, which recovered well-supported clades based on multilocus data matrices and yielded a robust, working hypothesis (Figs 1 and 4; Tables 2-4). However, our proposal for new names is conservative and focuses only on the more stable and robust nodes, often corroborated by morphological synapomorphies, aiming to minimize changes in the current classifications (Figs 1 and 4). Instead of filtering "problematic terminals" from our main results, we considered that they should be included in the main results because these specimens/molecular markers are available in GenBank as any other sequence. We acknowledge that this strategy resulted in somewhat controversial or not well supported positions, and therefore some of them are considered. Leptothecata incertae sedis (Lineages 1 and 2, rogue taxa), specific clades' incertae sedis (Lineages 3-5), and only a few as dubious terminals (e.g, potential taxonomic misidentifications).

Lafoeida sensu novum. Lafoeida sensu novum comprises only the three species sampled here by now and is presently defined by having stolonal or erect colonies, polyps without abcaulinar caecum, hydrothecae without operculum and diaphragm (considering other potential genera) and fixed gonophores, usually forming coppinia (aggregation of gonothecae that can include nematothecae ${ }^{4}$ ).

Previous analyses had placed Hebellinae, Zygophylacinae and Lafoeinae into the Lafoeidae (cf. Marques et al. $^{44}$ ) (Hebellidae and Zygophylacidae, respectively; Tables 3, S1, Figs 1 and 4), or related Zygophylacinae with Sertulariidae (cf. Marques et al. ${ }^{44}$ ). In our hypothesis, assumed to have a limited number of lafoeid species (Fig. 1, Table S1), Lafoeidae is the only nominotypic group of Lafoeida, not related to the "Hebellidae" and Zygophylacidae (see below), which is in agreement with previous studies ${ }^{35,43-45}$. Future addition of taxa will test that more properly.

Other molecular analyses indicate that Lafoeidae includes species of Filellum, Lafoea, Cryptolaria and Acryptolaria (Moura et al. ${ }^{43,50}$, present study), but its taxonomic range could be wider, because Grammaria (6 species) and Cryptolarella (1 species) were not included in our analyses. Altogether, the relationship of both genera with other Lafoeidae has been supported by morphology ${ }^{44,51}$. Another pending question about phylogenetic affinities for this family is its relationship with Clathrozoidae ${ }^{25,26}$, a family with two monospecific genera that has not been sampled in any published molecular phylogenetic analysis.

Hincksella sp. (traditionally considered as part of Syntheciidae) is the terminal that completes this clade. Morphological similarities between Syntheciidae and Lafoeidae species have already been identified ${ }^{52}$. Morphologically, the trophosome of Hincksella is similar to Lafoeida (e.g., Acryptolaria and Lafoea) because of the tubular hydrotheca. However, the proximal region of the hydrotheca of Hincksella has a distinct floor perforated by a hydropore ${ }^{53}$; additionally, species of Lafoeida, such as those of Acryptolaria and Lafoea, have coppinia (absent in Hincksella; but see Millard ${ }^{23}$ and Calder ${ }^{53}$ for opposing arguments on the affinity between Hincksella and Lafoeidae). Nonetheless, the hypothesis can only be tested with the inclusion of Parathuiaria (1 species) and Synthecium (23 species) in a broader analysis including multilocus data for Hincksella.

Additional references: Billard ${ }^{54}$; Rees \& Vervoort ${ }^{55}$; Vervoort $^{56}$; Migotto \& Marques $^{57}$; Schuchert $^{58}$; Marques et al. ${ }^{59,60}$; Bouillon et al. ${ }^{30}$; Peña Cantero et al. ${ }^{51}$.

Stegella lobata and Melicertum octocostatum (Lineage 1 - L 1). Stegella lobata belongs to the monotypic genus Stegella Stechow, 1919, which was previously associated with Campanulariidae ${ }^{61,62}$, and later included in Campanulinidae (Stechow 1919; originally as Stegella grandis ${ }^{63}$ ). It is characterized by pedicellate hydrothecae, rhizocaulomic colonies (hydrorhiza erect in parallel stolons), operculum with four flaps and fixed gonophores ${ }^{64,65}$.

Melicertum octocostatum belongs to the only genus of Melicertidae whose polyp stage is known. This family is divided in 4 genera and 8 species, and is characterized by stolonal colonies with unusual morphology when contrasted with the typical "thecate" polyp: absence of hydrotheca around the hydranth and probably with no gonotheca surrounding gonophores ${ }^{30}$. Medusae of this taxon have no ocelli or other marginal sensory structure ${ }^{4}$, but the gonads are on the radial canals, which is a typical character of the medusa of Leptothecata. In our phylogeny M. octocostatum is the basalmost leptothecate species with medusae with gonads on the radial canals.

The clade defined by S. lobata and M. octocostatum (Melicertidae) has a basal position in Leptothecata (Figs 1 and 2), similar to Leclère et al. ${ }^{45}$ but different from Peña Cantero et al. ${ }^{46}$. This group varies in both its affinities and nodal support, depending on the analysis (Leptothecata incertae sedis; Figs 1-3). Hopefully, sampling a higher number of species and additional markers will elucidate the relative positions of S. lobata and M. octocostatum. The same goes for other unsampled families of the superfamily Dipleurosomatoidea (Orchistomatidae - 6 species, Dipleurosomatidae - 8 species, Table S1).

Additional references: Bouillon ${ }^{25,26}$; Govindarajan et al. ${ }^{40}$.

Laodiceida taxon novum. Laodiceida taxon novum includes two families with medusae in their life cycles (Laodiceidae and Tiarannidae), although the medusa stage is still unknown in several species. However, in species where it is known, the medusa is characterized by the presence of gonads along the radial canals in Laodiceidae, and on the interradial walls of the stomach (or in adradial pouches) in Tiarannidae. Both groups have the pelagic stage with no statocysts but with cordyli ${ }^{4}$. The benthic stage has stolonal and erect (Stegopoma spp.) colonies, hydrothecae with operculum and diaphragm slightly developed or absent. 
A

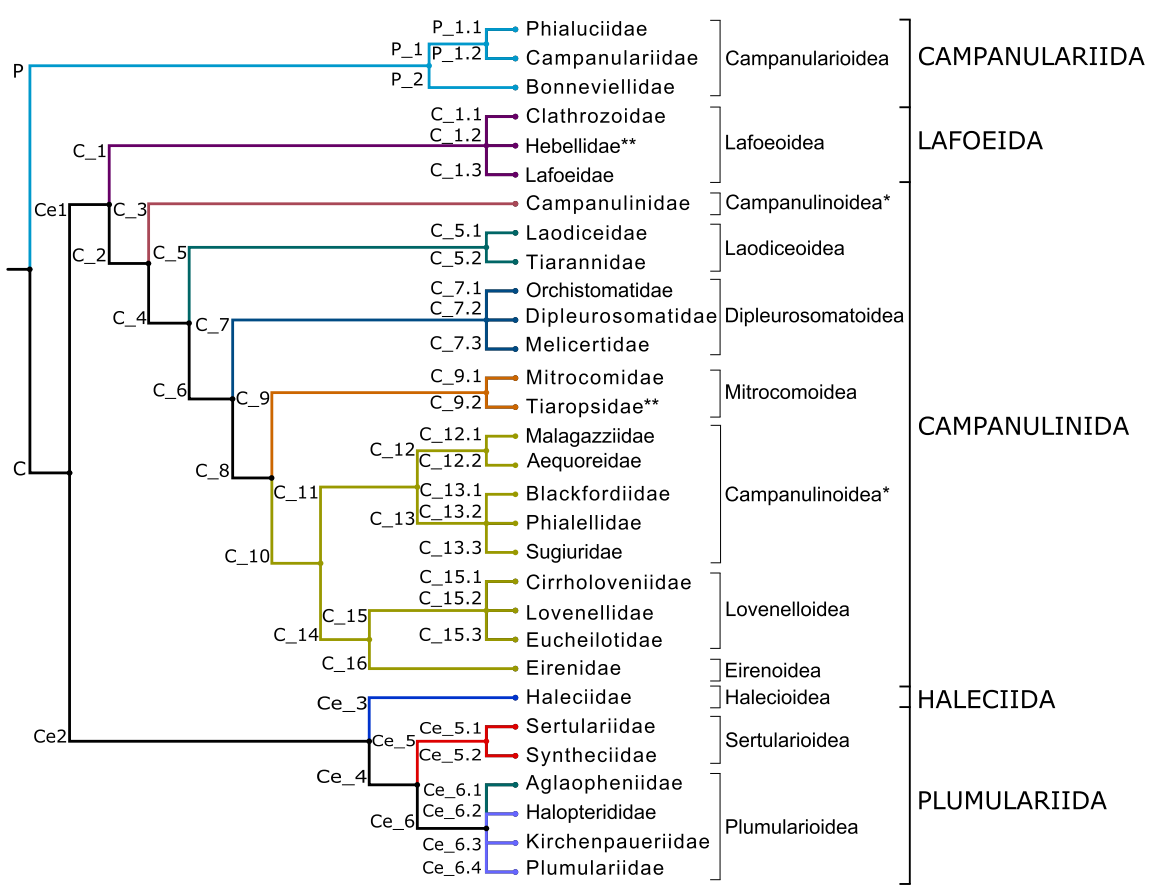

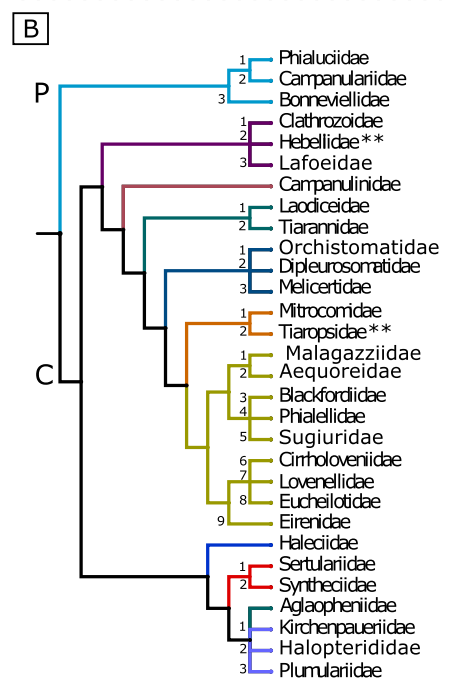

Bouillon (1995)

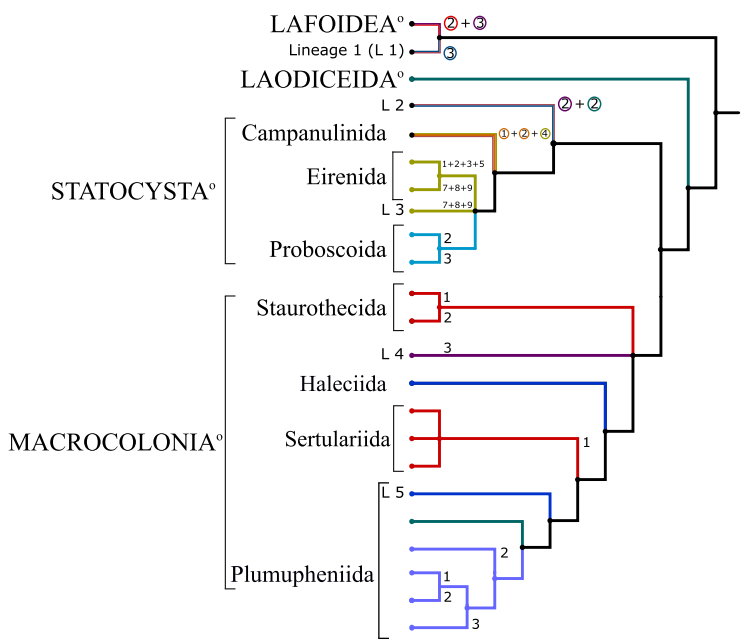

Current study

Figure 4. Cladogram (A): Classification of the Leptothecata following Bouillon ${ }^{28}$. Colors indicate representative clades. Codes at the base of the branches from Table 3. Asterisk indicates non-monophyletic, original proposal. Cladogram (B): comparison of the clades following Bouillon ${ }^{28}$ (left, defining the families) with the principal clades and lineages we propose herein (right, see Fig. 1); the symbol ${ }^{\circ}$ indicates clades already defined in the literature ${ }^{45}$. Colors indicate representative clades and the numbers at the bases of the branches indicate a summary of the relative position according to Bouillon ${ }^{28}$ and this study. Clades defined by more than one family in Bouillon ${ }^{28}$ are indicated by a combination of colors and number of the family in each case. Rogue taxa were not included and double asterisks indicate families absent from Bouillon ${ }^{28}$.

Monophyly of Laodiceida taxon novum and its phylogenetic position within Leptothecata are well supported (Table 2, Figs 1-3, cf. Leclère et al. ${ }^{45}$ ). According to our working hypothesis, Tiarannidae is not monophyletic and Laodiceidae becomes monophyletic only if Staurodiscus goto is not considered as part of the family (Fig. 1). Indeed, medusae of S. goto $i$ are morphologically similar to those of Hebella (Migotto \& Andrade ${ }^{66}$; cf. Leclère et al. ${ }^{45}$; Moura et al. ${ }^{43}$ ), suggesting homoplasy of the marginal cordyli in Staurodiscus and species that truly belong to Laodiceidae.

Discussions on the validity of the families of Laodiceida taxon novum have been focused on the position of the gonads in the medusae $e^{4,25,26,66}$, and some uncertainties still remain because several genera are poorly sampled, their life cycles are not fully known, and the polyp identification is complex, since their morphology is generally characterized as "cuspidella" type ${ }^{30}$. Also, Staurodiscus (type species Staurodiscus tetrastaurus Haeckel, 1879), whose monophyly remains uncertain, further confounds these issues. 


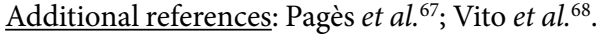

"Hebellidae", Staurodiscus gotoi (Lineage 2-L 2). This is a non-monophyletic lineage including three species of "Hebellidae" (Anthohebella parasitica, Hebella scandens, Hebella venusta) and S. gotoi (see considerations on Laodiceida taxon novum), with high support for the relative position of these species (Figs 1-3). Similar results were recovered elsewhere with a smaller set of "Hebellidae" species ${ }^{45}$. Also, the proximity between $S$. gotoi and "Hebellidae" reinforced previous considerations about misinterpretations of life cycles in these groups. The phylogenetic proximity between Scandia gigas and Haleciidae (Fig. 2), contrasts with its placement close to Hydrodendron gardineri and H. mirabile in Fig. 3 (genus traditionally considered as Haleciidae; Figs 1-3, Table 3), and also with its placement in our working hypothesis, firmly set in Sertularellidae (rogue taxon; Fig. 1). As already remarked, such instability might be attributed to the $16 \mathrm{~S}$ characters, thus we prefer to regard Lineage 2 as Leptothecata incertae sedis.

The phylogenetic basal position of L 2 and their life cycles (Hebella spp. and S. gotoi have medusae, Anthohebella has "swimming gonophores") corroborate the medusa as an ancestral condition in Leptothecata life history (Fig. 1). According to this hypothesis, the absence of medusae in the life cycle of Leptothecata would be a derived condition. "Hebellidae" and S. goto $i$ have stolonal colonies with campanulate hydrothecae provided with a diaphragm or annular thickening, and morphologically simple gonothecae ${ }^{44}$. While morphologically similar, other genera of "Hebellidae", such as Bedotella (1 species), with fixed gonophores, and Halisiphonia (5 species), which apparently has the medusa stage, need to be included in molecular and life cycle reconstruction analyse ${ }^{33,69}$.

Additional references: Calder $^{53}$; Cornelius ${ }^{4}$; Boero et al. ${ }^{70,71}$; Migotto et al. ${ }^{72}$.

Statocysta. Statocysta are characterized by having statocysts, a typical equilibrium structure of the medusa stage $^{45}$, indicative of a more active swimming. Two main lineages are well supported (Fig. 1): Campanulinida sensu novum and Eirenida taxon novum + Proboscoida sensu novum. Opercularella lacerata has a dubious position in our phylogenetic hypothesis (rogue taxa; Figs 1-3, Table 3). The traditional division of Leptothecata into Conica and Proboscoida is not supported because Statocysta combines parts of each one of these "taxa". Proboscoida, in its traditional sense, might be re-interpreted as a derived clade within Conica (Figs 1-4, Tables 3, S2). Future studies may infer alternative sister groups for Statocysta, especially considering those lineages included in Lineage 2 ("Hebellidae" and S. gotoi) and O. lacerata (rogue taxa).

Campanulinida sensu novum. This taxon includes species of several families and superfamilies of the traditional taxonomy (e.g., Mitrocomidae and Tiaropsidae), but its composition does not support the monophyly of Campanulinida in a traditional sense (cf. Bouillon ${ }^{25,26}$ ). Due to the difficulty of defining diagnostic characters for families and genera traditionally placed in Campanulinida ${ }^{4}$, the lack of information on life cycle and the difficulty in treating species with unrecognized medusae (e.g., Calycella and Campanulina; Bouillon et al..$^{30}$ ), the monophyly for these genera and families have often been questioned. A clear example of the need to understand more about life cycle strategies in Hydrozoa is found in Lafoeina (Campanulinidae) and Cirrholovenia. The benthic stage of Lafoeina species are mistakenly mixed with species of other taxa (e.g. Cuspidella species), in some cases with unknown medusa stage, and in others with young medusae strikingly similar to Cirrholovenia (genus of Lovenellidae, not represented in molecular studies ${ }^{72}$ ). Nomenclaturally, Campanulinidae is nominotypic, but rather a complex of species, whose problematic taxonomic status and identity have already been debated by other authors ${ }^{53}$. To solve the "campanulinid" taxonomy will be a major task in itself, beyond the scope of this manuscript. Therefore, we are aware that our hypothesis of Campanulinida sensu novum must be more broadly tested, including sequences of the type species of the genus Campanulina van Beneden, 1847 (Fig. 1).

None of the traditional lineages in Campanulinida is supported by our data, except the monophyly of Mitrocomidae (Figs 1-3, Tables 3, 4; Bouillon ${ }^{26}$ ). This is not surprising because there are no synapomorphies proposed for supraspecific taxa in the traditional Campanulinida ${ }^{1}$. In synthesis, morphology of the sampled species varies in the clade from the "cuspidella" type (stolonal colony, polyp with operculum but lacking diaphragm) to "generic campanulinida" (stolonal or erect colony, polyp with operculum and diaphragm). In those species with known medusa, this stage has four simple radial canals, many statocysts, hollow tentacles and no cirri (except Mitrocomella $)^{4,26}$.

Eirenida taxon novum. This clade comprises some of the remaining families traditionally assigned to Campanulinida (e.g., Aequoreidae, Eirenidae, Lovenellidae ${ }^{28}$ ). Two groups are revealed in our working hypothesis: Eirenids I and Eirenids II.

- Eirenids I. If corroborated, this clade will eventually become the nominotypical taxon because it includes species of the family Eirenidae Haeckel, $1879^{25,26}$ (non-monophyletic) and the genus Eirene Eschscholtz, 1829 (non-monophyletic), besides the type species of the genus, Eirene viridula (Péron \& Lesueur, 1809). It also includes several genera of Campanulinoidea and Eutonina (one of the two valid species in the taxon).

In an attempt to overcome the difficulty in defining diagnostic characters in Hydrozoa, Bouillon ${ }^{25,26}$ proposed the non-monophyletic clade "Campanulinoidea", characterized by "medusa without exumbrellar cirri" (with nomenclatural problems, N.B. the phylogenetic hypothesis in Bouillon ${ }^{25}$ : p. 12). In this hypothesis, a non-monophyletic Campanulinoidea included the problematic "Campanulinidae" (Fig. 4. and Table 3). Also, Eirene is complicated to diagnose, requiring the presence of the medusa stage for an adequate taxonomic identification; additionally, the medusa stage may also be found without cirri. Other groups external to Eirenids I have medusae lacking cirri (e.g., Phialellidae), and therefore, the state of character "medusa without cirri" is homoplastic.

Polyps of Eirenids I are "campanulinida" type, with stolonal colonies (except Aequorea and Eirene), operculum formed by flaps without clear demarcation from the hydrotheca, hydranths with intertentacular membrane and 
hydrotheca with diaphragm. Medusa has gonads on the radial canals, distant from the manubrium, ocelli and cirri are absent, and there are many closed statocysts (Cornelius ${ }^{4}$, Table 3 ). Internal relationships usually have weak support (Figs 1-3).

Additional references: Bouillon \& Boero ${ }^{29}$; Govindarajan et al. ${ }^{73}$; Kubota $^{74}$; Bardi \& Marques ${ }^{75}$; Leclère et al. ${ }^{45}$.

- Eirenids II. This clade comprises two subclades with high support (Figs 1-3): "Eirenidae" (polyphyletic traditional family, see above for considerations about Eirenids I) and two species of Lovenellidae (Eucheilota menoni and Eucheilota maculata; another species of Eucheilota appears in Statocysta Lineage 3 along with Lovenella gracilis).

One of the two main clades in Eirenids II includes the monophyletic genus Helgicirrha (with 2 sampled species), Hydranthea (considered as Lovenellidae by Bouillon et al. ${ }^{30}$ ) and Eucheilota (Lovenellidae). Its sister group includes species of Eutima and Eugymnanthea japonica, nested amongst them ${ }^{76}$. Eirenids II is interesting due to both morphology and lifestyle of the species: those of Eugymnanthea and Hydranthea produce eumedusoids and inhabit the mantle cavity of bivalves.

Eirenids II have "campanulinida" colonies, with reduced hydrotheca and hydranths protected by a slender perisarc and intertentacular membrane; medusa with gonads on the radial canals, lateral cirri and closed statocysts ${ }^{30}$.

Proboscoida sensu novum and Lineage 3 (L 3). Originally, Proboscoida included Bonneviellidae and Campanulariidae ${ }^{14}$, and later also Phialuciidae, being characterized mainly by the polyp with trumpet-shaped hypostome ${ }^{26}$. Except for Phialuciidae (monotypic family not included in this analysis), our topology provides support for phylogenetic proximity of the remaining Proboscoida, with the inclusion of Statocysta incertae sedis Lineage 3 (defined by Eucheilota bakeri + Lovenella gracilis and Eirene ceylonensis + Eirene menoni) as part of dubious results. In the Lovenellidae clade, our analysis groups E. bakeri with L. gracilis (Fig. 1). The origin of the GenBank sequences of $E$. bakeri is unknown to us and we suspect the material could have been incorrectly identified (part of conflicts are related to sequences' metadata ${ }^{77}$ ). We and other specialists (P. Schuchert, pers. comm.) agree on this possibility, and it would be necessary to examine the voucher to assure its identification. Historically, Lovenella has been associated to Campanulariidae (Hincks ${ }^{8}$, based on polyp characters), Lovenellidae (Russell ${ }^{78}$, based on medusa characters) and Campalecium (family Haleciidae, based on the "haleciid type" morphology of the polyp ${ }^{30}$ ). Hypotheses for Lovenellidae also included Eucheilota (Russell 1953), Cirrholovenia (Kramp 1959) and Hydranthea (see historical record in Miranda et al. ${ }^{79}$ ). Together with Eirenidae species, efforts on sampling additional molecular data for species of Lovenellidae are necessary to confirm its monophyly, or even to consider a possible resurrection of Eucheilotidae Bouillon, 1984. In our analysis, Proboscoida did not diverge firstly in Leptothecata as sister group of Conica, in contrast to the original proposal of the group (cf. Bouillon ${ }^{28}$ ).

Proboscoida sensu novum includes two highly-supported main clades, Campanulariida sensu novum and Obeliida taxon novum, the latter with high nodal support for apical groups as well (Figs 1-4, Tables 3 and 4).

- Campanulariida sensu novum. This taxon includes species of the traditional families Campanulariidae and Bonneviellidae. It is characterized by stolonal and erect colonies, occasionally polysiphonic (as in Rhizocaulus), with medusae or eumedusoids present (e.g., Orthopyxis; Cornelius ${ }^{24}$ ). No genus is recovered as monophyletic in our main results. Therefore, unresolved systematic questions, already discussed in literature ${ }^{80}$, still remain, such as the monophyly of Campanularia and Orthopyxis, which is related with taxonomic interpretations based on the presence/absence of diaphragm and the shape of hydrotheca (e.g., Millard ${ }^{23}$ ).

Additional references: Berrill ${ }^{81}$; Cunha et al. ${ }^{80}$; Govindarajan et al. ${ }^{40}$.

- Obeliida taxon novum. Obeliida taxon novum embraces the remaining families of Proboscoida, namely Clytiidae and Obeliidae (Table 4). Obeliidae is monophyletic with high nodal support (Fig. 3, topology 16S18S28S_Nrw4). Clytiidae sensu novum is monophyletic as well, despite the presence of "Eirene brevistylus" (probably due to a long-branch attraction artifact on $16 \mathrm{~S}$ sequences ${ }^{82}$ or to taxonomic misidentification) - presently this specimen is considered as incertae sedis. This clade is characterized by the presence of hydrothecae with diaphragm, and a wide variety of reproductive strategies: presence of uniform medusae (Obelia), meconid medusae (Gonothyraea) and fixed gonophores (Laomedea) ${ }^{5,24,83}$.

Additional references: Cornelius ${ }^{83}$; Govindarajan et al. ${ }^{84}$; Lindner et al..$^{85}$.

Billardia subrufa (Rogue taxa 4). The taxonomy of Billardia Totton, 1930 remains uncertain, and the genus has been morphologically associated either with Campanulariidae ${ }^{86}$, Lafoeidae and Syntheciidae ${ }^{23,24}$. Billardia colonies are erect, with no diaphragm or with an "annular thickening" at the base of the hydrotheca; gonophores are fixed and protected by a long, ringed gonotheca ${ }^{52,87}$. We obtained new sequences of the antarctic Billardia subrufa, similar to those of GenBank. Previous molecular analysis placed B. subrufa near to Lafoeidae, at the base of Leptothecata ${ }^{40,45}$. In our results, however, B. subrufa is at the base of Macrocolonia or proximal to Lafoeidae+Lineage 1 (Figs 1-3). The unstable position and low nodal support led us to consider $B$. subrufa as a leptothecate incertae sedis.

Additional references: Cornelius ${ }^{5}$.

Macrocolonia. Macrocolonia was proposed together with Statocysta, including groups with complex and erect colonies, and encompassing species of Plumularioidea, Sertulariidae and Haleciidae ${ }^{45}$. It mostly coincides with the traditional proposal of Plumulariida and Haleciida (original Haleciida included the family Syntheciidae; Bouillon ${ }^{25,28}$; Fig. 4, Table 3), being characterized by "Hydranthes à hypostome conique, et dont le feuillet endodermique est différencié em deux régions distinctes, hydranthes rétractables dans leurs hydrotèques, Celles-ci ont une 


\begin{tabular}{|c|c|c|}
\hline Principal clades & Bouillon (1995) & Represented Groups or Genera and/or // Species \\
\hline Order Lafoeida sensu novum & C_1.3 Ce_5.2* & Acryptolaria conferta, Lafoea dumosa, Hincksella sp. \\
\hline Order Laodiceida taxon novum & C_5 $5^{*}$ & Laodicea undulata, Modeeria rotunda, Melicertissa sp., Stegopoma plicatile \\
\hline Order Statocysta & C_ $3^{*} \mathrm{C}_{-} 5.2^{*} \mathrm{C}_{-} 8^{*} \mathrm{P} \_1.2^{*} \mathrm{P} \_2^{*}$ & (Campanulinida sensu novum (Eirenida taxon novum, Proboscoida sensu novum)) \\
\hline Suborder Campanulinida sensu novum & C_ $33^{*}$ C_ $9^{*}$ C_ $13.2^{*}$ C_5. $2^{*}$ & Mitrocomella, Campanulina*// Calycella syringa, Phialella quadrata, Tiaropsidium kelseyi, Tiaropsis multicirrata \\
\hline Suborder Eirenida taxon novum & C_1 $10^{*}$ & (Eirenids I, Eirenids II) \\
\hline Eirenids I & 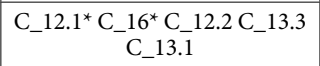 & $\begin{array}{l}\text { Aequorea*, Eirene* // Blackfordia virginica, Eutonina indicans, Octophialucium indicum, Rhacostoma atlanticum, } \\
\text { Sugiura chengshanense }\end{array}$ \\
\hline Eirenids II & C_16 $16^{*} \_15.3^{*}$ & Eucheilota*, Eutima* ${ }^{*}$, Helgicirrha // Hydranthea margarica, Eugymnanthea japonica \\
\hline Suborder Proboscoida sensu novum & P_1.2* P2* C_15.2* C_15.3* & (Campanulariida taxon novum, Obeliida taxon novum) \\
\hline Infraorder Campanulariida taxon novum & P_1.2*P_2* & Bonneviella*, Campanularia*, Orthopyxis ${ }^{*} / /$ Rhizocaulus verticillatus, Silicularia rosea \\
\hline Infraorder Obeliida taxon novum & C_ $15.2^{*} C_{-} 15.3^{*} P_{-} 1.2^{*}$ & Laomedea*, Obelia*, Clytia*//Eirene brevistylus ${ }^{* *}$, Gonothyraea loveni \\
\hline Order Macrocolonia & $\mathrm{Ce} \_2^{*}$ & (Staurothecida taxon novum (Haleciida sensu novum (Sertulariida taxon novum, Plumupheniida taxon novum)) \\
\hline Suborder Staurothecida taxon novum & $\mathrm{Ce}_{-} 5^{*}$ & Staurotheca, Antarctoscyphus, Symplectoscyphus ${ }^{*}$ \\
\hline Staurothecidae fam. nov. & Ce_5.2* & Staurotheca \\
\hline Symplectoscyphidae fam. nov. & Ce_5.1* & Antarctoscyphus, Symplectoscyphus* \\
\hline Suborder Haleciida sensu novum & $\mathrm{Ce}_{-} 3^{*}$ & Halecium \\
\hline Suborder Sertulariida taxon novum & $\mathrm{Ce}_{-} 5^{*}$ & (Sertularellidae fam. nov.(Thyroscyphidae, Sertulariidae sensu novum)) \\
\hline Sertularellidae fam. nov. & $\mathrm{Ce}_{-} 5^{*}$ & Sertularella // Symplectoscyphus turgidus** \\
\hline Thyroscyphidae & $\mathrm{Ce}_{-} 5^{*}$ & Thyroscyphus*// Sertularelloides cylindritheca \\
\hline Sertulariidae sensu novum & $\mathrm{Ce}_{-} 5^{*}$ & $\begin{array}{l}\text { Abietinaria, Amphisbetia, Diphasia, Dynamena*, Sertularia*, Thuiaria // Hydrallmania falcata, Idiellana pristis, } \\
\text { Salacia desmoides }\end{array}$ \\
\hline Suborder Plumupheniida taxon novum & $\mathrm{Ce} \_6^{*} \mathrm{Ce} \_3^{*}$ & (Aglaopheniida taxon novum, Plumulariida sensu novum) \\
\hline Infraorder Aglaopheniida taxon novum & Ce_6.1 & Aglaophenia ${ }^{*}$, Gymnangium ${ }^{*}$, Lytocarpia $^{*}$, Macrorhynchia // Cladocarpus integer \\
\hline Infraorder Plumulariida sensu novum & Ce_6.2Ce_6. $33^{*} \mathrm{Ce} \_6.4$ & (Schizotrichidae (Kirchenpaueriidae, Halopterididae, Plumulariidae)) \\
\hline Schizotrichidae & Ce_6.3* & Schizotricha \\
\hline Kirchenpaueriidae & Ce_6.2 & Oswaldella // Kirchenpaueria pinnata, Pycnotheca mirabilis, Ventromma halecioides \\
\hline Halopterididae & Ce_6. $3^{*}$ & Antennella*, Halopteris*// Monostaechas quadridens, Polyplumaria flabellata \\
\hline Plumulariidae & Ce_6.4 $4^{*}$ & Nemertesia, Plumularia $* / /$ Dentitheca bidentata \\
\hline
\end{tabular}

Table 4. Clades in the working hypothesis (Fig. 1) compared with those of Bouillon ${ }^{28}$. Single asterisks $\left({ }^{*}\right)$ denote non-monophyletic groups in Fig. 1 (topology 16S18S28S_N), considering traditional taxonomy from WoRMS database; double asterisks ${ }^{* *}$ ) indicate dubious information so far. Because of their unstable or poorly supported placements, lineages and rogue taxa were not included. For a phylogenetic description of differences between our results and Bouillon ${ }^{28}$, see Fig. 4 .

symétrie bilatérale, sont dépourvues de diaphragme mais leur plancher est perforé par un hydropore" (Bouillon ${ }^{25}$, p. 20 ${ }^{88}$. Macrocolonia has the greatest species richness within Medusozoa, with the medusa stage reduced and with fixed gonophores in most part of the species. Our hypothesis emphasizes the proposal of some new taxa, as well as readjustments in already defined taxa. We do not find it necessary to reinterpret Macrocolonia. Rather, we point out the relative positions of both Macrocolonia incertae sedis: Lineage 4 (Zygophylacinae) and Lineage 5 (Nemalecium lighti and H. mirabile), together with interesting evolutionary aspects concerning Staurotheca and Schizotricha.

Staurothecida taxon novum - Staurothecidae fam. nov. and Symplectoscyphidae fam. nov. At the base of Macrocolonia, Plumulariida, Sertularioidea and Sertulariidae are not monophyletic, which contradicts the traditional taxonomic view of these taxa within Leptothecata ${ }^{5}$. In our present understanding, a basal branch of Macrocolonia includes a weakly supported clade that we have named as Staurothecida taxon novum to preserve the taxonomic logic of Leptothecata. Staurothecida taxon novum includes two new well-supported families that support previously described patterns ${ }^{46}$ : Staurothecidae fam. nov. and Symplectoscyphidae fam. nov.

Staurothecidae fam. nov. includes the type-genus Staurotheca Allman, 1888 and its species, which were previously attributed to Syntheciidae $\mathrm{e}^{23,25,26,28,89,90}$ and Sertulariidae ${ }^{91}$. Morphologically, Staurothecidae and Staurotheca are characterized by tubular hydrothecae, with operculum and diaphragm arranged either in two longitudinal rows of opposite, sub-opposite or alternate hydrothecae or in decussate series. Male and female gonothecae are directly inserted at the hydrothecal base, with female gonothecae sometimes arranged on special supporting structures (Peña Cantero \& Vervoort ${ }^{92}$, p. 2664).

Symplectoscyphidae fam. nov. includes the type-genus Symplectoscyphus Marktanner-Turneretscher, 1890 and the genus Antarctoscyphus, both of them historically related (cf. Peña Cantero et al. ${ }^{91}$ ). Like Staurotheca, Symplectoscyphus is also a monophyletic taxonomically stable taxon (e.g., Peña Cantero et al. ${ }^{46}$ ). We corroborated this taxon and we characterize Symplectoscyphidae fam. nov. by the hydrothecal aperture provided with three cusps and by an operculum of three valves. Nonetheless, the genera vary in colony morphology, branching pattern and gonotheca morphology (Peña Cantero et al. ${ }^{91}$, p. 24). Symplectoscyphus curvatus has to be taxonomically revalidated, since it is sister group of Antarctoscyphus species (Figs 1-3). Also, the identity of Symplectoscyphus turgidus 
specimen used here was confirmed by P. Schuchert (pers. comm.) and therefore, its placement within Sertularella has to be re-evaluated.

Additional references: Peña Cantero et al. ${ }^{46,90,91}$; Peña Cantero \& Vervoort ${ }^{92,93}$; Peña Cantero ${ }^{94}$.

Haleciida, Halecioidea, Haleciidae sensu novum. Haleciidae sensu novum (and the redundant taxa Halecioidea and Haleciida) encompasses only species of Halecium Oken, 1815. It is a homogeneous and monophyletic taxon, sister group of Sertulariida taxon novum and Plumupheniida taxon novum. The complex taxonomic history of the taxa was reviewed by Calder ${ }^{53}$, Schuchert ${ }^{95}$ and Peña Cantero ${ }^{96}$. Some genera previously attributed to Haleciidae were placed in Plumulariidae and Lafoeidae due to the presence of nematothecae ${ }^{97}$, which are absent in species of Halecium ${ }^{23}$. In our topology, the genera Hydrodendron and Nemalecium have an alternative position, related to Plumularioidea (Lineage 5; Figs 1-3).

Halecium colonies are erect and ramified, often with free hydrophores. The hydrotheca is shallow, with conspicuous proximal desmocytes, and with hydranth not retractable into it. The gonophores are fixed and protected in solitary gonothecae or aggregated in glomulus, usually dimorphic (cf. Calder ${ }^{53}$ ).

Additional references: Cornelius ${ }^{5}$; Schuchert ${ }^{95}$; Peña Cantero ${ }^{96}$.

Zygophylacinae (Lineage 4). Zygophylacidae was considered several times to be a subfamily of Lafoeidae (Zygophylacinae) due to the presence of bilateral and tubular hydrotheca ${ }^{44,53}$. Here, the sampled species of Zygophylacinae occupy alternative positions in Macrocolonia as sister group of Sertulariida+Plumupheniida (Fig. 1), Haleciida (Fig. 2) and Staurotheca (Fig. 3). All these relative positions with low support are likely to be related to the exclusive use of $16 \mathrm{~S}$ marker in our analyses for these species. Zygophylacinae has already been considered as Sertulariidae, related to Abietinaria, due to the form of the colonies, the presence of operculum (present in Abietinella) and the hydrothecal shape ${ }^{98}$. Despite being within Macrocolonia, the species of Zygophylacinae here analysed have characters not found in other members of Sertulariida, Staurotheciida or Haleciida sensu novum, such as the presence of nematothecae and gonothecae aggregated into coppinia or scapus ${ }^{44}$. Because of their incertae sedis position among Macrocolonia, and features as defensive polyps (as present in Plumupheniida), a multilocus analysis would better define their position. Their basal "condition" called our attention to a speculative scenario, where Zygophylacinae resulted in a family group (as already discussed by Moura ${ }^{43}$ ), as a basal lineage of Macrocolonia, or directly related to Plumupheniida.

Sertulariida taxon novum. Traditionally, sertulariids are well-supported taxa defined by their colony shape and hydrothecal morphology, although these characters are plastic, and integrative proposals have been questioned $^{99}$. Sertulariidae was firstly split into three subfamilies (Sertulariinae, Thyroscyphinae and Sertomminae), mainly based on whether hydrothecae were sessile or pedicellate, and on the presence-absence of abcaulinar cecum $^{53,63}$. The current scope of Sertulariida taxon novum, however, includes several sertulariid species that are herein classified among families with new interpretations, such as Thyroscyphidae and Sertulariidae sensu novum, besides the new taxon Sertularellidae fam. nov. Other groups, on the other hand, were removed from Sertulariidae (see Staurothecidae and Symplectoscyphidae above). Overall, Sertulariida taxon novum is characterized by stolonal or erect monopodial colonies, with radial to bilateral symmetry on hydrothecae, hydrothecal margin with 3 to 4 cusps, operculum of 2 to 4 valves, and fixed gonophores (except for Amphisbetia operculata (Linnaeus, 1758) and Sertularia marginata (Kirchenpauer, 1864), which are medusoid-producing species). Below, we present our new interpretations and descriptions within Sertulariida taxon novum:

- Sertularellidae fam. nov. This is a well-supported clade, including the highly speciose genus Sertularella Gray, 1848 with 131 nominal species distributed worldwide ${ }^{3}$. Colonies are erect, mono- or polysiphonic, branched or unbranched, and hydrothecae have four marginal cusps and a pyramidal operculum with four triangular valves ${ }^{53}$. Our results call attention to a possible reinterpretation of $S$. turgidus as part of Sertullarellidae, and supports Sertularelloides cylindritheca as a Thyroscyphidae species, as already discussed ${ }^{100}$. Further samples for these species will be of great value, mainly because until now there is only one specimen sampled for S. turgidus ${ }^{45}$ (Fig. 1; see below).

Additional references: Vervoort ${ }^{98,101}$; Vervoort \& Watson ${ }^{102}$.

- Thyroscyphidae. Morphologically, Thyroscyphidae includes species with pedicellate hydrotheca, with annular diaphragm and hydranths with a double basal annulus instead of abcaulinar diverticulum. Traditionally, the family includes Thyroscyphus, Parascyphus, Sertularelloides, Thyroscyphoides, Uniscyphus and Symmetroscyphus ${ }^{2,53}$. Historically, Thyroscyphidae is monophyletic, either considered as a separate clade from Sertulariidae (e.g., Calder ${ }^{53}$; Shimabukuro \& Marques ${ }^{88}$ ), or as part of Sertulariidae (cf. Millard ${ }^{23}$; Bouillon ${ }^{26}$ ). We keep Thyroscyphidae at the family rank because of its high support and coincidence with other similar hypotheses ${ }^{45,100}$, although small changes in the position of Thyroscyphus might occur. We include S. cylindritheca (previously Sertularella cylindritheca) in Thyroscyphidae ${ }^{46,100}$, but this species will need further analysis, including Parascyphus, because of its uncertain affinities (cf. Calder ${ }^{53}$ ).

- Sertulariidae sensu novum. A redefinition of the taxa within Sertulariidae sensu stricto is required, due to our proposal involving new families (i.e., Sertularellidae, Staurothecidae and Symplectoscyphidae). In its current scope, many genera still need to be sampled and validated, and even the richest genera (e.g., Sertularia and Dynamena) are not considered monophyletic in our hypothesis, as already presented and discussed ${ }^{45,100}$; morphological features, such as the abcauline diverticulum (cf. Calder ${ }^{53}$ p. 86-87), still have to be tested as synapomorphies. Sertulariidae sensu novum includes species with hydrothecae with non-pyramidal operculum, with one (e.g., 
Abietinaria, Diphasia, Idiellana, Salacia, Thuiaria) or two valves (the adcaulinar one sometimes divided into two, e.g., Amphisbetia, Dynamena, Hydrallmania, Sertularia). These characters are homoplastic in our working hypothesis; other characters also proved to be equally uninformative, such as fasciculation, hydrothecal arrangement and shape of hydrothecal aperture. It is noteworthy to highlight that the non-monophyly of Sertularia raises back the question about the validity of Tridendata Stechow, 1920. Indeed, Sertularia argentea (type species of Sertularia), and Sertularia perpusilla (type species of Tridentata) falls apart in our hypotheses (Figs 1-3), and several of the species usually assigned to the genus Tridentata (e.g., Tridentata marginata, Tridentata turbinata, Tridentata tumida) are close to the type species T. perpusilla (D.R. Calder, pers. comm.). The addition of new sertulariid taxa and sequences shall provide a better test for this hypothesis, but presently it surely cannot be discarded. Sertulariidae sensu novum has decreased its species richness, since traditional genera such as Sertularella, Antarctoscyphus and Symplectoscyphus (representing $\sim 41 \%$ of the number of species in Sertulariidae sensu stricto ${ }^{3}$ ) are not here considered within the family.

Additional references: Berrill ${ }^{103}$; Calder $^{53}$; Cornelius $^{4,5}$; Migotto ${ }^{104}$; Marques et al. $^{59}$.

Plumupheniida taxon novum. $\quad$. lighti and H. mirabile have unstable positions, but generally related to the clades Aglaopheniida taxon novum and Plumulariida sensu novum. Except for N. lighti and H. mirabile, Aglaopheniida taxon novum and Plumulariida taxon novum are characterized by uniseriate hydrothecae $5,25,26,28,45,46$ (Figs 1-3). Concerning the taxonomy, Plumupheniida has a different taxonomic comprehensiveness from Plumularioidea McCrady, $1859^{3}$ because N. lighti and H. mirabile are included in this clade based on multilocus data (similar situation for Aglaopheniida and Aglaopheniidae; see below and Table 3).

Nemalecium lighti and Hydrodendron mirabile (Lineage 5 - L 5). Traditionally considered as haleciids, $N$. lighti and $H$. mirabile were not recovered as a monophyletic group, or as closely related to Haleciida; therefore they are considered Plumupheniida incertae sedis. Nemalecium lighti is remarkable in having "swimming gonophores" with corpuscles that may be related to buoyancy ${ }^{105}$. This character is also found in some Plumulariidae (e.g., Macrorhynchia philippina cf. Gravier-Bonnet \& Migotto ${ }^{105}$ ) and Aglaopheniidae (e.g., Dentitheca bidentata $\mathrm{cf}$. Migotto \& Marques ${ }^{57}$ ). The presence of "nematodactyls" in the ring of tentacles ${ }^{106}$ should be reanalyzed concerning its organization, because it may be homologous to nematophores ${ }^{53}$, which would corroborate the affinity of Nemalecium with the Plumupheniida. However, future analyses are still necessary to better investigate this question and to test the position of $N$. lighti with respect to the rest of Plumupheniida, especially concerning other traditional "haleciids".

Hydrodendron mirabile is highly supported as sister group of Aglaopheniida, and shares the presence of nematophores and nematothecae with Aglaopheniida+Plumulariida sensu novum. Defense polyps, therefore, are corroborated as a possible synapomorphic condition of Plumulariida + Aglaopheniida $+H$. mirabile (Fig. 1-3), and not as a convergence (Leclère et al. ${ }^{41}$; corrobating a posterior result ${ }^{45}$ ). The taxonomic position of $H$. mirabile, however, has to be tested with the inclusion of additional molecular data for $H$. gardineri and other terminals of Hydrodendron, a genus with ca. 25 nominal species ${ }^{2}$.

Additional references: Rees \& Vervoort ${ }^{55}$; Vervoort ${ }^{56}$; Cornelius $^{5}$.

Aglaopheniida taxon novum. Aglaopheniida has a high nodal support (see also references ${ }^{41,42,45}$ ). Some proposals are incongruent with our topology, because Gymnangiinae/Aglaopheniinae, and Aglaopheniini/ Cladocarpini ${ }^{107}$ are not monophyletic due to the position of Gymnangium gracilicaule and Lytocarpia sp. Also, all traditional genera of Aglaopheniidae, except by Macrorhynchia, are not monophyletic in our proposal (Fig. 1; see also previous analyses ${ }^{45}$ ). Aglaopheniida is characterized by having paired lateral nematothecae partially fused to the hydrotheca, all nematothecae one-chambered and immovable ${ }^{46}$. Part of the taxon has gonothecae protected by phylactocarps or corbulae ${ }^{5}$.

Additional references: Gravier ${ }^{108}$; Svoboda \& Cornelius ${ }^{109}$.

Plumulariida sensu novum. Plumulariida sensu novum has a high nodal support and includes four families characterized by free nematothecae and bilateral symmetry of the hydrotheca in many species. Our cladogram shows Schizotrichidae as sister group of the rest of Plumulariida sensu novum (Figs 1-3), instead of sister group of Aglaopheniidae, as originally proposed ${ }^{46}$. Our proposal of the relationship among the other three families (viz., Halopterididae, Kirchenpaueriidae and Plumulariidae; Figs 1-3) is different from that previously proposed (cf. Leclère et al. ${ }^{41}$ ). The topology (Kirchenpaueriidae (Halopterididae, Plumulariidae)) (cf. Leclère et al. ${ }^{45}$; Peña Cantero et al. ${ }^{46}$ ) refutes the absence of cauline hydrothecae as synapomorphy for Plumulariidae, Kirchenpaueriidae and Aglaopheniidae ${ }^{45,110}$.

Kirchenpaueriidae is characterized by the absence of paired lateral nematothecae, and the presence of one to two mesial nematophores, naked or with reduced nematothecae, associated with each hydrothecae, usually also reduced $^{45}$. Kirchenpaueriidae was traditionally considered as sister group of other Plumulariida due to the simple morphology of the nematothecae ${ }^{90}$, which are similar to those of Haleciidae ${ }^{107}$. However, our phylogeny does not corroborate this hypothesis, since Schizotrichidae has a basal position in Plumulariida sensu novum. Our phylogenetic relationships within Kirchenpaueriidae are as previously thought ${ }^{111}$ : Ventromma is a monophyletic group (cf. Calder 1997 ${ }^{107}$; Peña Cantero \& Marques ${ }^{112}$ ) not synonymous of Kirchenpaueria (cf. Millard ${ }^{23}$; Bouillon ${ }^{26}$ ), which differs from Ventromma by the presence of naked sarcostyles ${ }^{107}$. In our topology, Kirchenpaueria pinnata, Pycnotheca mirabilis and species of Oswaldella define a monophyletic group. Oswaldella is a monophyletic group with high support and geographic distribution restricted to Antarctica and Patagonia shelf ${ }^{12-114}$. Further studies with molecular and morphological data should focus on the taxonomic affinities of Halicornopsis, Ophinella and Wimveria. 
As stated above, Halopterididae becomes monophyletic with the exclusion of Schizotrichidae (viz., Peña Cantero et al. $^{46}$ ) and the inclusion of Polyplumaria flabellata ${ }^{5,107,110}$. Amendments of the diagnosis based on morphological characters of Halopterididae was proposed by Peña Cantero et al. ${ }^{46}$. The genera traditionally considered as Halopterididae are not monophyletic (e.g. Halopteris Allman, 1877, cf. Leclère et al. ${ }^{41,45}$; Peña Cantero et al. ${ }^{46}$ ), and the shape of the colony as the main character to define their taxonomical limits might be questionable ${ }^{110}$. Halopteris is divided into several high-supported clades. Halopteris carinata Allman, 1877, type species of Halopteris, has different morphology from many of the species traditionally assigned to the genus (except for Halopteris liechtensternii (Marktanner-Turneretscher, 1890)), and the hypothesis that genera of Halopterididae are not monophyletic can be supported by morphology as well as molecular data (Dale Calder, pers. comm.). The position of species of Antennella on the topology (Figs 1-3) supports multiple origins of simplified colonies from the pinnate ancestral form ${ }^{110}$. Four genera (i.e., Anarthoclada, Astrolabia, Nuditheca and Pentatheca) have to be included in further analysis, especially because they have already been considered as Aglaopheniidae ${ }^{30}$, Halopterididae ${ }^{107,110}$ and Schizotrichidae ${ }^{46}$.

Plumulariidae is defined by our molecular data as sister group of Kirchenpaueriidae+Halopterididae, and it is also morphologically well defined ${ }^{46}$ (Figs 1-3). The taxonomy of the group, however, is troubled, because the genera are poorly defined and the species share many plastic characters ${ }^{107}$. Two well-supported clades were found in Plumulariidae: one includes the non-monophyletic genera Dentitheca and species of Plumularia (Plumularia spiralis, Plumularia habereri and Plumularia insignis); the other includes the 9 remaining Plumularia and 2 species of Nemertesia (Nemertesia antennina and Nemertesia ventriculiformis). In our phylogeny, Nemertesia is monophyletic and related to Plumularia species, a different relationship from previous study ${ }^{115}$. Overall, our results are congruent with the proposals of the current literature based on genetic data ${ }^{41,45,46}$.

Additional references: Millard ${ }^{116}$; Ansín Agís et al. ${ }^{117}$; Schuchert ${ }^{118}$.

Evolutionary scenarios, life cycle and biogeography. Traditional evolutionary scenarios for Leptothecata may be either inadequate or speculative because of the lack of data, and sometimes because of a grounded phylogenetic framework. For instance, the hypothesis that erect, complex colonies without the medusa stage, such as those of Macrocolonia, would be an eventual energetic tradeoff for medusa suppression (discussed in Cornelius ${ }^{31}$ ), or the evolution of the "swimming gonophores"119, are not based on phylogenetic hypotheses.

However, one could say that the evolution of Leptothecata supports an interpretation of adaptive radiation ${ }^{120}$, both by having high rates of lineage diversification with morphological innovations (e.g., colony structure), and diversified ecological properties (e.g., benthic life cycle). On the other hand, extinction rates are difficult to estimate because of the limited fossil data, which severely restrict our knowledge on the historical distribution of ancestral lineages. Several alternative hypotheses may explain the rapid diversification of Leptothecata ${ }^{45,121,122}$. For instance, loss of the medusa stage, together with the reduction in the number of larvae, would result in phylopatric species with long-lived, sessile polyp stages (cf. Thiel \& Gutow $^{123}$ ).

Yet, when trying to explain potential advantages for presence or absence of the medusa stage, there are different interpretations. According to Leclère et $\mathrm{al}^{45}$ (p. 510 our emphasis), the high number of convergent medusa losses/reductions observed among hydrozoans strongly suggests that getting rid of the pelagic stage is positively selected under some circumstances, leading Cornelius ${ }^{121}$ to emphasize a challenging paradox: "if medusa loss is advantageous, and if it can evolve easily, then why have not all recent forms dispensed with the medusa long ago?" However, Cornelius stated that the paradox condition was the loss of the "advantageous medusa stage": "The widespread loss of the medusa stage is a paradox in view of its presumed advantage and undoubted complexity" (Cornelius $^{31}$, p. 249, our emphasis).

Leclère et al. ${ }^{45}$ proposed an explanation for the evolution of different life cycles strategies ${ }^{124}$. In their scenario, species with simple colonies (such as those typical of Statocysta) would invest more in the reproductive and dispersive pelagic stage, with a benthic stage in which the planula quickly settles on living substrates (with less competition and greater tolerance to environmental stress). On the other hand, species with erect, complex colonies, without medusa (like those typical of Macrocolonia), would strongly compete for the substrate and have limited dispersal abilities, which could result in low gene flow and consequent local speciation. The (homoplastic) appearance of species with medusoids in lineages that lost the medusa could, in turn, be explained by high rates of extinction of clades that do not acquire reproductive or dispersive benefits, limiting the phenomenon of colonial brooding ${ }^{44}$. Thus, it is clear that these ideas presume greater dispersal ability of the pelagic adult stages (cf. Gibbons et al. ${ }^{125,126}$ with Cornelius ${ }^{31,121,127}$ ).

Our data support the interpretation of dispersal and rapid settling in Statocysta, in contrast with competitiveness in Macrocolonia. Because of that, stasis (cf. Eldredge et al. ${ }^{128}$ ) may have predominated in lineages with medusa stage ${ }^{45}$. However, mechanisms associated with the speciation process in Macrocolonia would not be just a product of dispersal limitations. Other factors, even combined with those previously discussed, may have been important in the exploration of new potential ecological niches, genetic diversity and diversification success (e.g., parental investment ${ }^{129}$ ). The first mechanism is the type of fertilization (Miller ${ }^{130}$; discussed in Corynidae and Obeliinae by Panteleeva ${ }^{131}$ ), which is widely debated in other modular organisms such as tunicates and bryozoans ${ }^{132,133}$. Overall, hydrozoans with the medusa stage in the life cycle spawn gametes directly to the environment (e.g., Laodicea), while those without the medusa stage retain the unfertilized egg, presenting internal fertilization, sometimes with incubation (e.g., some Diphasia species). The second mechanism is associated with the strength and robustness of the colonies, especially those with a main axis with erect monopodial growth and branches that are strengthened by the fusion of the hydrotheca to the perisarc ${ }^{134}$. The third mechanism concerns the increasing in modular and morphological complexity, reflected in the high occurrence of nematophores/nematothecae in complex and reproductive defense structures ${ }^{135,136}$, such as the phylactocarps and the corbulae in Aglaopheniida. In this case, the polyp stage would live longer than the medusa stage, reducing the periodicity of the life cycle and increasing the rate of anagenesis ${ }^{31}$. 
All these mechanisms modulate levels of endemism in different biogeographic scenarios of Hydrozoa. Cornelius ${ }^{31,137}$ discussed several hypotheses in favor of the prevalence of the polyp stage as the main mechanism of dispersal in Hydrozoa, such as the high-energetic cost of producing a medusa stage, the small-size of the hydroid colonies that release medusa, the different realms occupied by the two stages and the difficulties of interchanges between them, the large-size of the colonies that do not produce medusa and tend to perennate, the brief life span of the medusa stage, and the low chances of two sexually different medusa to arrive at the same time in a long-distant area, to reproduce and to develop a new hydroid colony. In this context, we may hypothesize on one hand, that species with both polyp and medusa stages in the life cycle may have greater endemicity than those with only polyp or medusa stage in the life $c c^{3}{ }^{31,121}$. On the other hand, species with both polyp and medusa stages in the life cycle are less common in remote areas of the deep sea and at distant places from the continental shelves ${ }^{138,139}$, as well as in regions with extreme environmental conditions (e.g., Antarctic, Arctic, hydrothermal vents). However, few biogeographic studies dealing with the level of endemicity and/or areas of endemism in Hydrozoa species were fully carried out, with this being an open question to be better explored through different biogeographic methods. Another interesting biogeographical pattern in Macrocolonia is seen in Staurothecida taxon novum, where Staurotheca, Symplectoscyphus and Antarctoscyphus are widely represented in Antarctic and sub-Antarctic waters, supporting a unique phylogenetic history. In contrast, other genera of Sertulariida taxon novum (e.g., Amphisbetia, Diphasia, Dynamena, Sertularia and Thyroscyphus) have an antipolar distribution. Results of ecological niche modeling ${ }^{140}$ of Bougainvilliidae show that, probably, the potential niche (and correlated areas) of distribution of certain species is the sum of ecological restrictions of polyps and medusae, which strongly limits distribution. Therefore, the presence of both stages in the life cycle results in narrower potential areas to be colonized. We conclude that reductionism in scenarios of advantages and disadvantages of the medusa stage are oversimplifications of complex evolutionary processes. It is also evident that the evolution of the life-cycle strategies has consequences for the understanding of species distributions and biogeography.

Final considerations. Evidences accumulated during the last decades on morphology and life cycle of leptothecates demand new interpretations on the evolution of the group, especially because traditional taxonomy is incongruent with the recent phylogenetic hypotheses. Monophyly of many traditional taxa (e.g., Sertulariidae) is not supported, although some patterns remain strong, such as orders Statocysta and Macrocolonia (Table 4). Therefore, we propose a phylogenetic taxonomical reorganization of Leptothecata down to the infraorder level, but considering only the well-supported clades. Although most of main traditional groups were sampled in this study, we emphasize that several taxa (e.g., from species up to the family level) have not been included yet in broad phylogenetic analyses, and those clades must be intregrated to this classificatory framework in the near future:

Superorder Leptothecata Cornelius, 1992

Order Lafoeida Bouillon, 1984, sensu novum

Order Laodiceida taxon novum

Order Statocysta Leclère, Schuchert, Cruaud, Couloux, Manuel, 2009

Suborder Campanulinida Bouillon, 1984, sensu novum

Suborder Eirenida taxon novum

Suborder Proboscoida Broch, 1910 sensu novum

Infraorder Campanulariida Bouillon, 1984, sensu novum

Infraorder Obeliida taxon novum

Order Macrocolonia Leclère, Schuchert, Cruaud, Couloux, Manuel, 2009

Suborder Staurothecida taxon novum [includes Staurothecidae fam. nov. and Symplectoscyphidae fam. nov.]

Suborder Haleciida Bouillon, 1984 sensu novum

Suborder Sertulariida taxon novum [includes Sertularellidae fam. nov.]

Suborder Plumupheniida taxon novum

Infraorder Aglaopheniida taxon novum

Infraorder Plumulariida Bouillon, 1984 sensu novum

\begin{abstract}
Methods
Taxonomic sampling and data. We generated new data for 74 nominal species of Leptothecata for a total of 220 terminals in the combined analysis. Forty-three additional species were used as outgroups (14 new sampled species incorporated in this study): 27 "Anthoathecata", 7 Siphonophorae Eschscholtz, 1829 and 9 Trachylina species ("Trachylinae" in the original description from Haeckel, 1879, p. 233), totaling 263 hydrozoan species (Table S1).

We developed a workflow considering alternative protocols to extract total DNA of adequate molecular weight from a variety of tissues (from rich-mesoglea medusae and rich-chitin benthic colonies). Extractions were carried out with the Bio- $\operatorname{Rad}^{\circledR}$ INSTAGENE kit (based on the Chelex caotrophic component ${ }^{141}$ ) by using a volume (concentration) adjustment in the one-step extraction reaction. This is important for micro samples when the concentration had to be optimized. If the extraction proved to be difficult, or otherwise unsatisfactory, we then used the Agencourt ${ }^{\circledR}$ DNAdvance kit, in which total DNA is separated from the remaining lysed cell-tissues by means of magnetic particles with high affinity for double-stranded DNA. Quality control of both methods was carried out with a Thermo ${ }^{\circledR}$ NanoDrop 2000c spectrophotometer. Subsequently, we used typical PCR with the appropriate primers and annealing temperatures $(\mathrm{Tm})$ for each molecular marker of interest (see Supplementary Tables S2, S3 online). Following the control for successful PCR on 1.5\% agarose gel (stained with Biotium ${ }^{\circledR}$ GelRed), the double-stranded DNA PCR products were purified with the Agencourt ${ }^{\circledR}$ AMPure ${ }^{\circledR}$ kit (final purified DNA concentrations were checked with Thermo ${ }^{\circledR}$ NanoDrop 2000c). The sequencing reaction was carried out with
\end{abstract}


the ABI Big Dye V3.1 ${ }^{\circledR}$ kit, under standard conditions using the original PCR primers and Tm conditions. Final precipitation of DNA was carried out with ammonium acetate and ethanol ${ }^{142}$ and samples were sequenced in the Hitachi ${ }^{\circledR}$ ABI PRISM3100 genetic analyzer ${ }^{\circledR}$ (IQUSP). Chromatograms were mounted in GeneCodes Sequencer 4.6 and Geneious v5.4 $4^{143}$. Controls for potential contamination error on the consensus sequences were made using BLAST on GenBank and local databases ${ }^{144}$. Final sequences were submitted to GenBank using Geneious v5.4 $4^{143}$ (procedure summarized in Fig. S1).

Primers combinations used for each molecular marker amplified almost complete nuclear ribosomal sequences (small ribosomal subunit, or $18 \mathrm{~S}$, with $\sim 1,800 \mathrm{pb}$; large ribosomal subunit, $28 \mathrm{~S}$, with $\sim 3,200 \mathrm{pb}$ ) and part of the mitochondrial molecular marker (large mitochondrial subunit, or $16 \mathrm{~S}$, with $\sim 600 \mathrm{pb}$ ). Sequence generation success, considering species and marker, together with voucher codes and collecting locations are summarized in Table S1 and Fig. S2. Along with our samples including as many species as possible for the ingroup, we sampled species from the rest of Hydrozoa as outgroups compiling a supermatrix dataset ${ }^{145}$ (Table S1). Names of species and higher taxonomic units were compared with those in WoRMS (World Hydrozoa Database ${ }^{2}$ genus-level taxonomy) and Bouillon ${ }^{28}$ (family-level taxonomy) with a few exceptions (Tables 1, 4, S3 and S4 for details of primers and protocols).

Alignment, filtering strategies and molecular marker combinations. Alignments were performed using MAFFT v6 $6^{146}$ using the E-INS-i algorithm. After the trimming of low quality regions from the $5^{\prime}$ and $3^{\prime}$ ends of the individual alignments, we used Aliscore to eliminate saturated and ambiguously aligned regions with two levels of filtration ${ }^{147}$. At the first filtration level (light), gaps are treated as missing data (similar to treatment of gaps in phylogenetic analysis, command $-\mathrm{N}$ ) and an $\mathrm{N}$ was added to the acronym designating the resulting matrices (e.g., the marker $16 \mathrm{~S}$ becomes 16S_N). We employed the default window size (i.e. 6 residues). In the next filtering level (heavy), the moving windows size was reduced to the minimum allowed by the algorithm and the resulting matrices received a "_Nrw4" suffix (e.g., 18S results in "18S_Nrw4"). Thus, each marker was present in three aligned data matrices: raw (that is, unedited, e.g., 18S), light filtering of hypervariable regions (e.g., 18S_N) and heavily filtered (e.g., 18S_Nrw4). Finally, concatenated data matrices were assembled using SequenceMatrix ${ }^{148}$ for every case (a full data matrix, named 16S18S28S, lightly filtered datamatrix16S18S28S_N and heavily filtered damatrix 16S18S28S_Nrw4), with matrices of up to 6,000bp (Tables 1 and 2). Thus, our datamatrix strategy permitted two different approximations, allowing us to obtain single and multilocus phylogenies, with and without filtration in each case, making up a total of 12 individual phylogenetic analyses (Table 2).

Phylogenetic analysis and support. We carried out $250 \mathrm{ML}$ tree searches on each data matrix using RAxML v8 ${ }^{149}$ under default settings with a gamma distribution (generated by the data) and no invariable sites $\left(\right.$ GTR + GAMMA, following the software manual) in CIPRES portal ${ }^{150}$. For multilocus data matrices were partitioned by gene (Table 2). For support, considering parametric methods we used aLRT (approximate likelihood ratio test) and aBAYES (approximate transformation Bayes test), and for non-parametric methods we used the Bootstrap (BS) and SH-aLRT ${ }^{48,151}$. Bootstrap analyses for multilocus matrices were carried out in RAxML v7.3.0. ( 1,000 replicas in conditions similar to the original analysis). Values for aLRT, SH-aLRT and aBAYES were calculated for each optimal ML tree from RAxML (multilocus and individual) in PhyML 3.0.1 beta ${ }^{152}$ (parameters similar to those in RAxML). Anisimova et al. ${ }^{48}$ present a comprehensive comparison of the four measures of node support listed above with respect to their levels of sensitivity and specificity. Using simulated data, those authors concluded that the most widely used measure of node support (non-parametric bootstrapping - BS) is too conservative i.e., many nodes present in the tree that was used to simulate the analyzed data were not significantly supported by bootstrapping under the same model employed in the simulation. Here, we report as significantly supported not only the nodes whose BS values are equal or greater than $75 \%$, but also the nodes that had support values equal or above the thresholds obtained by Anisimova et al. ${ }^{48}$ (aBAYES > 0.95; aLRT > 0.9; SH-aLRT > 0.85 ), even if BS nodal support was not significant (i.e. $<0.75$ ). Marker saturation conditions for $16 \mathrm{~S}$ and $18 \mathrm{~S}$ were evaluated with figures of transitions versus transversions in $\mathrm{DAMBE}^{153}$ (Fig. S12).

In order to detect rogue taxa, nonparametric bootstrap pseudo-replicates obtained from concatenated matrices were analyzed using the online version of RogueNaRok ${ }^{154}$ (http://rnr.h-its.org), under default parameters. The top ten rogue taxa were deleted from every combined data matrix and these new, "reduced" matrices were re-analyzed as the original ones. These analyses were used to assess rogue taxa's potential impact on the broad phylogenetic picture of the Leptothecata and to pinpoint taxa with conflicting positions across topologies obtained from matrices with different levels of noise filtering (for further information see Supplementary Text, Supplementary Tables S4, S5, and Supplementary Figs S13-S15). Access to main data (Figshare database): http://dx.doi.org/10.6084/ m9.figshare. 1556316 .

\section{References}

1. Daly, M. et al. The phylum Cnidaria: A review of phylogenetic patterns and diversity 300 years after Linnaeus. Zootaxa 1668, 127-182 (2007).

2. Schuchert, P. Hydrozoa in World Register of Marine Species (2014). Available at: http://www.marinespecies.org/aphia. php? $\mathrm{p}=$ taxdetails\&id $=1337$. (Accessed: $24 / 03 / 2015)$.

3. Schuchert, P. World Hydrozoa Database (2014). Available at: http://www.marinespecies.org/hydrozoa. (Accessed: 24/03/2015).

4. Cornelius, P. F. S. North-West European thecate hydroids and their medusae: part 1 introduction, Laodiceidae to Haleciidae: keys and notes for identification of the species. Synopses of the British Fauna-New Series- No.50 [Barnes, R. S. K., Crothers, J. H. (ed.)] [347 pp.] (Field Studies Council, Shrewsbury, 1995).

5. Cornelius, P. F. S. North-West European thecate hydroids and their medusae: part 2 Sertulariidae to Campanulariidae: keys and notes for identification of the species. Synopses of the British Fauna-New Series- No.50 [Barnes, R. S. K., Crothers, J. H. (ed.)] [386 pp.] (Field Studies Council, Shrewsbury, 1995).

6. Fleming, J. A. history of British animals. [565 pp.] (Bell and Bradfute, Edinburgh, 1828).

7. Sars, M. Bidrag til Söedyrenes Naturhistorie. 1e Haefte. Bergen. Résumé dans: Isis, 1833, 221 (1829). 
8. Hincks, T. A history of the British hydroid zoophytes. Volume I-Text. [334 pp.] (Van Voorst and Paternoster Row, London, 1868).

9. Cornelius, P. F. S. The linking of polyp and medusa stages in Obelia and other coelenterates. Biol. J. Linn. Soc. 9, 45-57 (1977).

10. Calder, D. R. The Reverend Thomas Hincks FRS (1818-1899): taxonomist of Bryozoa and Hydrozoa. Arch. Nat. Hist. 36, 189-217 (2009).

11. Allman, G. J. On the construction and limitation of genera among the Hydroida. Ann. Mag. Nat. Hist. 3rd Ser. 13, 345-380 (1864).

12. Allman, G. J. A monograph of the gymnoblastic or tubularian hydroids. I. The Hydroida in general. [154 pp.] (The Ray Society by R. Hardwicke, London, 1871).

13. Haeckel, E. Das System der Medusen. Erster Thiel einer Monographic der Medusen. Erste Hälfte des ersten Theils: System der Craspedoten. Denkschr. med. naturw. Ges. Jena 1, 1-360 (1879).

14. Broch, H. Die Hydroiden der arktischen Meere. Fauna Arctica 5, 127-248 (1910).

15. Rees, W. J. Evolutionary trends in the classification of capitate hydroids and medusae. Bull. Br. Mus. nat. Hist., Zool. 4, 453-534 (1957).

16. Naumov, D. V. Gidroidy i gidromedusy morskikh, solonovatovodnykh i presnovodnykh basseinov S.S.S.R. Fauna S.S.S.R. 70, 1-626 (1960).

17. Naumov, D. V. Hydroids and hydromedusae of the U.S.S.R. Fauna U.S.S.R. 70, 1-626 (1969).

18. Cornelius, P. F. S. Donat Vladimirovich Naumov (1921-1984). Modern trends systematics, ecology, and evolution of hydroids and hydromedusae [Bouillon, J., Boero, F., Cicogna, F. \& Cornelius, P. F. S. (ed)] [5-7] (Clarendon Press, Oxford, 1987).

19. Hincks, T. On new British Hydroida. Ann. Mag. Nat. Hist. 3rd Ser. 3, 296-299 (1866).

20. Hincks, T. On Ophiodes, a new genus of Hydroida. Ann. Mag. Nat. Hist. 3rd Ser. 3, 421-423 (1866)

21. Hincks, T. Notes on Norwegian Hydroida from deep water. Ann. Mag. Nat. Hist. 4rd Ser. 4, 125-137 (1874).

22. Morton, J. E. Mosaic evolution in hydroids. Nature 180, 130-131 (1957).

23. Millard, N. A. H. Monograph on the Hydroida of southern Africa. Ann. South African Museum 68, 1-513 (1975).

24. Cornelius, P. F. S. Hydroids and medusae of the family Campanulariidae recorded from the eastern North Atlantic, with a world synopsis of genera. Bull. Br. Museum (Natural Hist. 42, 37-148 (1982).

25. Bouillon, J. Révision de la famille des Phialuciidae (Kramp, 1955) (Leptomedusae, Hydrozoa, Cnidaria), avec un essai de classification des Thecatae-Leptomedusae. Indo-Malayan Zool. 1, 1-24 (1984).

26. Bouillon, J. Essai de classification des hydropolypes-hydroméduses (Hydrozoa-Cnidaria). Indo-Malayan Zool. 2, 29-243 (1985).

27. Petersen, K. W. Evolution and taxonomy in capitate hydroids and medusae (Cnidaria: Hydrozoa). Zool. J. Linn. Soc. 100, 101-231 (1990).

28. Bouillon, J. Classe des Hydrozoaires. Traité de Zoologie. Tome III, Fascicule 2: Cnidaires, Cténaires [Grassé, P. P. \& Doumenc, D. (ed)] [29-416] (Masson, Paris, 1995).

29. Bouillon, J. \& Boero, F. The Hydrozoa: a new classification in the light of old knowledge. Thalassia Salentina 24, 3-45 (2000).

30. Bouillon, J., Gravili, C., Pagès, F., Gili, J. M. \& Boero, F. An introduction to Hydrozoa. Mémoires du Muséum Natl. d'Histoire Nat. 194, 1-591 (2006)

31. Cornelius, P. F. S. Medusa loss in leptolid Hydrozoa (Cnidaria), hydroid rafting, and abreviated life-cycles among their remote-island faunae: an interim review. Sci. Mar. 56, 245-261 (1992).

32. Marques, A. C. Simplifying hydrozoan classification: inappropriateness of the group Hydroidomedusae in a phylogenetic context. Contrib. to Zool. 70, 175-179 (2001).

33. Marques, A. C. \& Collins, A. G. Cladistic analysis of Medusozoa and cnidarian evolution. Invertebr. Biol. 123, 23-42 (2004).

34. Collins, A. G. Towards understanding the phylogenetic history of Hydrozoa: hypothesis testing with $18 \mathrm{~S}$ gene sequence data. Sci. Mar. 64, 5-22 (2000).

35. Cartwright, P. et al. Phylogenetics of Hydroidolina (Hydrozoa: Cnidaria). J. Mar. Biol. Assoc. United Kingdom 88, 1663-1672 (2008).

36. Collins, A. G. et al. Phylogenetics of Trachylina (Cnidaria: Hydrozoa) with new insights on the evolution of some problematical taxa. J. Mar. Biol. Assoc. United Kingdom 88, 1673-1685 (2008).

37. Collins, A. G. Recent insights into cnidarian phylogeny. Smithson. Contrib. Mar. Sci. 139-149 (2009).

38. Van Iten, H., Marques, A. C., Leme, J. de M., Pacheco, M. L. A. F. \& Simões, M. G. Origin and early diversification of the phylum Cnidaria Verrill: major developments in the analysis of the taxon's Proterozoic-Cambrian history. Palaeontology 57, 677-690 (2014).

39. Collins, A. G. et al. Medusozoan phylogeny and character evolution clarified by new large and small subunit rDNA data and an assessment of the utility of phylogenetic mixture models. Syst. Biol. 55, 97-115 (2006).

40. Govindarajan, A. F., Boero, F. \& Halanych, K. M. Phylogenetic analysis with multiple markers indicates repeated loss of the adult medusa stage in Campanulariidae (Hydrozoa, Cnidaria). Mol. Phylogenet. Evol. 38, 820-34 (2006).

41. Leclère, L., Schuchert, P. \& Manuel, M. Phylogeny of the Plumularioidea (Hydrozoa, Leptothecata): evolution of colonial organisation and life cycle. Zool. Scr. 36, 371-394 (2007).

42. Moura, C. J., Cunha, M. R., Porteiro, F. M. \& Rogers, A. D. A molecular phylogenetic appraisal of the systematics of the Aglaopheniidae (Cnidaria: Hydrozoa, Leptothecata) from the north-east Atlantic and west Mediterranean. Zool. J. Linn. Soc. 164, 717-727 (2012).

43. Moura, C. J., Cunha, M. R., Porteiro, F. M. \& Rogers, A. D. Polyphyly and cryptic diversity in the hydrozoan families Lafoeidae and Hebellidae (Cnidaria:Hydrozoa). Invertebr. Syst. 25, 454-470 (2011).

44. Marques, A. C., Peña Cantero, A. L. \& Migotto, A. E. An overview of the phylogeny of the families Lafoeidae and Hebellidae (Hydrozoa:Leptothecata): their composition and classification. Invertebr. Syst. 20, 43-58 (2006).

45. Leclère, L., Schuchert, P., Cruaud, C., Couloux, A. \& Manuel, M. Molecular phylogenetics of Thecata (Hydrozoa, Cnidaria) reveals long-term maintenance of life history traits despite high frequency of recent character changes. Syst. Biol. 58, 509-526 (2009).

46. Peña Cantero, A. L., Sentandreu, V. \& Latorre, A. Phylogenetic relationships of the endemic Antarctic benthic hydroids (Cnidaria, Hydrozoa): what does the mitochondrial 16S rRNA tell us about it? Polar Biol. 33, 41-57 (2010).

47. Collins, A. G., Winkelmann, S., Hadrys, H. \& Schierwater, B. Phylogeny of Capitata and Corynidae (Cnidaria, Hydrozoa) in light of mitochondrial 16S rDNA data. Zool. Scr. 34, 91-99 (2005).

48. Anisimova, M., Gil, M., Dufayard, J.-F., Dessimoz, C. \& Gascuel, O. Survey of branch support methods demonstrates accuracy, power, and robustness of fast likelihood-based approximation schemes. Syst. Biol. 60, 685-99 (2011).

49. Cartwright, P. \& Nawrocki, A. M. Character evolution in Hydrozoa (phylum Cnidaria). Integr. Comp. Biol. 50, 456-72 (2010).

50. Moura, C. J., Harris, D. J., Cunha, M. R. \& Rogers, A. D. DNA barcoding reveals cryptic diversity in marine hydroids (Cnidaria, Hydrozoa) from coastal and deep-sea environments. Zool. Scr. 37, 93-108 (2008).

51. Peña Cantero, A. L., Marques, A. C. \& Migotto, A. E. Revision of the genus Acryptolaria Norman, 1875 (Cnidaria, Hydrozoa, Lafoeidae). J. Nat. Hist. 41, 229-291 (2007).

52. Ralph, P. M. New Zealand thecate hydroids. Part I.- Campanulariidae and Campanulinidae. Trans. R. Soc. New Zeal. 84, 811-854 (1957).

53. Calder, D. R. Shallow-Water hydroids of Bermuda: The Thecatae, exclusive of Plumularioidea. Estuaries 14, 1-140 (Royal Ontario Museum, 1991).

54. Billard, A. Notes sur quelques espèces d'hydroïdes de l'expédition du "Siboga". Arch. Zool. Expérimentale Générale Notes Rev. 57, 21-27 (1918).

55. Rees, W. J. \& Vervoort, W. Hydroids from the John Murray Expedition to the Indian Ocean, with revisory notes on Hydrodendron, Abietinella, Cryptolaria and Zygophylax (Coelenterata: Hydrozoa). Zool. Meded. 237, 1-209 (1987). 
56. Vervoort, W. Evaluation of taxonomic characters in the Hydroida, particularly in the Thecata (= Leptomedusae). Modern trends in the systematics, ecology, and evolution of hydroids and hydromedusae [Bouillon, J., Boero, F., Cicogna, F. \& Cornelius, P. F. S. (ed)] [83-103] (Clarendon Press, Oxford, 1987).

57. Migotto, A. E. \& Marques, A. C. Redescription of Dentitheca bidentata (Cnidaria: Hydrozoa, Plumulariidae), with notes on its life cycle. J. Nat. Hist. 33, 949-960 (1999).

58. Schuchert, P. Hydroids of Greenland and Iceland (Cnidaria, Hydrozoa). Bioscience 53, 1-184 (2001).

59. Marques, A. C., Peña Cantero, A. L. \& Migotto, A. E. Revision of the genus Cryptolarella Stechow, 1913 (Lafoeidae, Leptothecata, Hydrozoa). J. Nat. Hist. 39, 709-722 (2005).

60. Marques, A. C., Peña Cantero, A. L., Miranda, T. P. \& Migotto, A. E. Revision of the genus Filellum Hincks, 1868 (Lafoeidae, Leptothecata, Hydrozoa). Zootaxa 1-28 (2011).

61. Hickson, S. J. \& Gravely, F. H. Hydroid zoophytes. National Antarctic expedition (S.S. "Discovery") 1901-1904. Nat. Hist. 3, 1-34 (1907).

62. Vanhöffen, E. Die Hydroiden der deutschen Südpolar-Expedition 1901-1903. Dtsch. Südpolar-Expedition 11 (=Zoology 3), 269-340 (1910).

63. Stechow, E. Neue Ergebnisse auf dem Gebiete der Hydroidenforschung. München. mediz. Wochenschr. (30) 852-853 (1919).

64. Blanco, O. M., Zamponi, M. O. \& Genzano, G. N. Campanulinidae de la Argentina (Coelenterata, Hydrozoa, Hydroida). Rev. del Mus. La Plata 14, 267-278 (2000).

65. Vervoort, W. Hydroids from the Theta, Vema and Yelcho cruises of the Lamont-Doherty Geological Observatory. Zool. Verh. 120, $1-247$ (1972).

66. Migotto, A. E. \& Andrade, L. P. The life cycle of Hebella furax (Cnidaria: Hydrozoa): a link between a lafoeid hydroid and a laodiceid medusa. J. Nat. Hist. 34, 1871-1888 (2000).

67. Pàges, F., Gili, J. M. \& Bouillon, J. Medusae (Hydrozoa, Scyphozoa, Cubozoa) of the Benguela Current (southeastern Atlantic). Sci. Mar. 56, 1-64 (1992).

68. Vito, D., Piraino, S., Schmich, J., Bouillon, J. \& Boero, F. Evidence of reverse development in Leptomedusae (Cnidaria, Hydrozoa): the case of Laodicea undulata (Forbes and Goodsir 1851). Mar. Biol. 149, 339-346 (2006).

69. Marques, A. C., Peña Cantero, A. L. \& Migotto, A. E. Revision of Halisiphonia Allman, 1888 (Cnidaria, Hydrozoa, Hebellidae), with comments on its taxonomic position. J. Nat. Hist. 40, 1047-1062 (2006).

70. Boero, F. \& Sarà, M. Motile sexual stages and evolution of Leptomedusae (Cnidaria). Ital. J. Zool. 54, 131-139 (1987).

71. Boero, F., Bouillon, J. \& Kubota, S. The medusae of some species of Hebella Allman, 1888, and Anthohebella gen. nov.(Cnidaria, Hydrozoa, Lafoeidae), with a world synopsis of species. Zool. Verh. 310, 1-53 (1997).

72. Migotto, A. E. \& Cabral, A. S. Lafoeina amirantensis (Cnidaria: Hydrozoa, Campanulinoidea), the hydroid stage of the medusa Cirrholovenia tetranema (Cnidaria: Hydrozoa, Lovenelloidea). Zootaxa 1-16 (2005).

73. Govindarajan, A. F., Piraino, S., Gravili, C. \& Kubota, S. Species identification of bivalve-inhabiting marine hydrozoans of the genus Eugymnanthea. Invertebr. Biol. 124, 1-10 (2005).

74. Kubota, S. Constant timing of medusa release in bivalve-inhabiting hydrozoans of the genus Eugymnanthea (Hydrozoa: Leptomedusae: Eirenidae). J. Mar. Biol. Assoc. United Kingdom 88, 1607-1609 (2008)

75. Bardi, J. \& Marques, A. C. The invasive hydromedusa Blackfordia virginica (Cnidaria: Blackfordiidae) in southern Brazil, with comments on taxonomy and distribution of the genus Blackfordia. Zootaxa 2198, 41-50 (2009).

76. Kubota, S. Parallel, paedomorphic evolutionary processes of the bivalve-inhabiting hydrozoans (Leptomedusae, Eirenidae) deduced from the morphology, life cycle and biogeography, with special reference to taxonomic treatment of Eugymnanthea. Sci. Mar. 64, $241-247(2000)$

77. Marques, A. C., Maronna, M. M. \& Collins, A. G. Putting GenBank data on the map. Science 341, 1341 (2013)

78. Russell, F. S. The medusae of the British Isles. Anthomedusae, Leptomedusae, Limnomedusae, Trachymedusae and Narcomedusa [522 pp] (Cambridge University Press, Cambridge, 1953).

79. Miranda, T. P., Cunha, A. F. \& Marques, A. C. Taxonomic position of Lovenella gracilis Clarke, 1882 (Lovenellidae, Hydrozoa): new evidences of microanatomy justify its maintenance in the genus Lovenella Hincks, 1868. Lat. Am. J. Aquat. Res. 41, 286-295 (2013).

80. Cunha, A. F., Genzano, G. N. \& Marques, A. C. Reassessment of morphological diagnostic characters and species boundaries requires taxonomical changes for the genus Orthopyxis L. Agassiz, 1862 (Campanulariidae, Hydrozoa) and some related campanulariids. PLOS ONE 2, e0117553.

81. Berrill, N. J. Growth and form in calyptoblastic hydroids. II. Polymorphism within the campanularidae. J. Morphol. 87, 1-26 (1950).

82. Zheng, L., He, J., Lin, Y., Cao, W. \& Zhang, W. 16S rRNA is a better choice than COI for DNA barcoding hydrozoans in the coastal waters of China. Acta Oceanol. Sin. 33, 55-76 (2014)

83. Cornelius, P. F. S. European Obelia (Cnidaria, Hydroida): systematics and identification. J. Nat. Hist. 24, 535-578 (1990).

84. Govindarajan, A. F., Halanych, K. M. \& Cunningham, C. W. Mitochondrial evolution and phylogeography in the hydrozoan Obelia geniculata (Cnidaria). Mar. Biol. 146, 213-222 (2004).

85. Lindner, A., Govindarajan, A. F. \& Migotto, A. E. Cryptic species, life cycles, and the phylogeny of Clytia (Cnidaria: Hydrozoa: Campanulariidae). Zootaxa 2980, 23-36 (2011).

86. Totton, K. A. Hydroida. British Antarctic ("Terra Nova”) Expedition, 1910. Nat. Hist. Reports 5, 131-252 (1930).

87. Blanco, O. M. Nueva Billardia (Hydrozoa, Campanulariidae) con modificación de la diagnosis del género. Neotrópica 13, 117-120 (1967).

88. Shimabukuro, V. \& Marques, A. C. Morphometrical analysis, histology and taxonomy of Thyroscyphus ramosus (Cnidaria, Hydrozoa) from the coast of Brazil. Zootaxa 1184, 29-42 (2006).

89. Stechow, E. Zur Kenntis der Hydroidenfauna des Mittelmeeres, Amerikas und anderer Gebiete. II. Teil. Zool. Jb., Syst. 47, 29-270 (1923).

90. Peña Cantero, A. L., Svoboda, A. \& Vervoort, W. Species of Staurotheca Allman, 1888 (Cnidaria: Hydrozoa) from recent antarctic expeditions with R. V. Polarstern, with the description of six new species. J. Nat. Hist. 31, 329-381 (1997).

91. Peña Cantero, A. L., Carrascosa, A. M. G. \& Vervoort, W. On Antarctoscyphus (Cnidaria, Hydrozoa), a new genus of antarctic hydroids and the description of two new species. Polar Biol. 18, 23-32 (1997).

92. Peña Cantero, A. L. \& Vervoort, W. Species of Staurotheca Allman, 1888 (Cnidaria: Hydrozoa: Sertulariidae) from US Antarctic expeditions, with the description of three new species. J. Nat. Hist. 37, 2653-2722 (2003).

93. Peña Cantero, A. L. \& Vervoort, W. Sertularia echinocarpa Allman, 1888, an unexpected new species of Staurotheca Allman, 1888 (Cnidaria: Hydrozoa: Sertulariidae). Zoölogische Meded. 77, 537-543 (2003).

94. Peña Cantero, A. L. On a new Antarctic species of Symplectoscyphus Marktanner-Turneretscher 1890 (Cnidaria, Hydrozoa, Sertulariidae), with an annotated checklist of the Antarctic species of the genus. Zootaxa 29-44 (2010).

95. Schuchert, P. Taxonomic revision and systematic notes on some Halecium species (Cnidaria, Hydrozoa). J. Nat. Hist. 39, 607-639 (2005).

96. Peña Cantero, A. L. Revision of the Antarctic species of Halecium Oken, 1815 (Cnidaria, Hydrozoa, Haleciidae). Zootaxa 3790, 243-80 (2014).

97. Fraser, C. M. Distribution and relationship in American hydroids [464 pp] (University of Toronto Press, Toronto, 1946).

98. Peña Cantero, A. L. \& García-Carrascosa, A. M. The coppinia of Abietinella operculata (Lafoeidae: Hydrozoa Leptomedusae) and its systematic position. J. Nat. Hist. 27, 1003-1011 (1993). 
99. Nutting, C. C. American hydroids. Part II. The Sertulariidae. United States Natl. Museum. Spec. Bull. 4, 1-325 (1904).

100. Moura, C. J., Cunha, M. R., Porteiro, F. M. \& Rogers, A. D. The use of the DNA barcode gene $16 \mathrm{~S}$ mRNA for the clarification of taxonomic problems within the family Sertulariidae (Cnidaria, Hydrozoa). Zool. Scr. 40, 520-537 (2011).

101. Vervoort, W. Cnidaria, Hydrozoa, Hydroida: Hydroids from the Western Pacific (Philippines, Indonesia and New Caledonia), I: Sertulariidae (Part 1). Résultats des Campagnes MUSORSTOM vol. II. Mémoires du Muséum Natl. d'Histoire Nat. 158, 89-298 (1993).

102. Vervoort, W. \& Watson, J. E. The Marine Fauna of New Zealand: Leptothecata (Cnidaria:Hydrozoa) (Thecate Hydroids)[538 pp] (National Institute of Water and Atmospheric Research Biodiversity memoir 119, Wellington, 2003).

103. Berrill, N. J. Growth and form in calyptoblastic hydroids. I. Comparison of a campanulid, campanularian, sertularian and plumularian. J. Morphol. 85, 297-335 (1949).

104. Migotto, A. E. The life cycle of Sertularia marginata Kirchenpauer, 1864 (Cnidaria: Hydrozoa): a medusoid-producing sertulariid. J. Nat. Hist. 32, 1-12 (1998).

105. Gravier-Bonnet, N. \& Migotto, A. E. Gonangium development and medusoid of Nemalecium lighti (Hargitt, 1924) (Cnidaria: Hydrozoa, Haleciidae). Sci. Mar. 64, 207-213 (2000).

106. Hargitt, C. W. Hydroids of the Philippine islands. Philipp. J. Sci. 24, 467-507 (1924).

107. Calder, D. R. Shallow-water hydroids of Bermuda: superfamily Plumularioidea. R. Ont. Mus. Life Sci. Contrib. 161, 1-85 (1997).

108. Gravier, N. Libération des médusoides par Macrorhynchia philippina Kirchenpauer, 1872 (Hydroida, Plumulariidae). Recl Trav. Stn mar. Endoume, n. ser., suppl. 10, 253-257 (1970).

109. Svoboda, A. \& Cornelius, P. F. S. The European and Mediterranean species of Aglaophenia (Cnidaria Hydrozoa). Zool. Verh. 274, 1-72 (1991).

110. Schuchert, P. Review of the family Halopterididae (Hydrozoa, Cnidaria). Zool. Verh. 309, 1-162 (1997)

111. Peña Cantero, A. L. Benthic hydroids (Cnidaria, Hydrozoa) from the Balleny Islands (Antarctica). Polar Biol. 32, 1743-1751 (2009).

112. Peña Cantero, A. L. \& Marques, A. C. Phylogenetic analysis of the Antarctic genus Oswaldella Stechow, 1919 (Hydrozoa, Leptomedusae, Kirchenpaueriidae). Contrib. to Zool. 68, 83-93 (1999).

113. Marques, A. C. \& Peña Cantero, A. L. Areas of endemism in the Antarctic - a case study of the benthic hydrozoan genus Oswaldella (Cnidaria, Kirchenpaueriidae). J. Biogeogr. 37, 617-623 (2010).

114. Miranda, T. P., Peña Cantero, A. L. \& Marques, A. C. Southern Ocean areas of endemism: a reanalysis using benthic hydroids (Cnidaria, Hydrozoa). Lat. Am. J. Aquat. Res. 41, 1003-1009 (2013).

115. Moura, C. J., Cunha, M. R., Porteiro, F. M., Yesson, C. \& Rogers, A. D. Evolution of Nemertesia hydroids (Cnidaria: Hydrozoa, Plumulariidae) from the shallow and deep waters of the NE Atlantic and western Mediterranean. Zool. Scr. 41, 79-96 (2012).

116. Millard, N. A. H. The Hydrozoa of the south and west coasts of South Africa. Part I. The Plumulariidae. Ann. South African Museum 46, 261-319 (1962).

117. Ansín Agís, J., Vervoort, W. \& Ramil, F. Atlantic Leptolida (Hydrozoa, Cnidaria) of the families Aglaopheniidae, Halopterididae, Kirchenpaueriidae and Plumulariidae collected during the CANCAP and Mauritania-II expeditions of the National Museum of Natural History, Leiden, the Netherlands. Zool. Verh. 333, 1-268 (2001).

118. Schuchert, P. High genetic diversity in the hydroid Plumularia setacea: a multitude of cryptic species or extensive population subdivision? Mol. Phylogenet. Evol. 76, 1-9 (2014).

119. Boero, F., Bouillon, J., Piraino, S. \& Schmid, V. Diversity of hydroidomedusan life cycles: ecological implications and evolutionary patterns. Proc. 6th Int. Conf. Coelenterate Biol. 1995, 53-62 (1997). URN: nbn:nl:ui:29-24108.

120. Glor, R. E. Phylogenetic insights on adaptive radiation. Annu. Rev. Ecol. Evol. Syst. 41, 251-270 (2010).

121. Cornelius, P. F. S. Evolution in leptolid life-cycles (Cnidaria: Hydroida). J. Nat. Hist. 24, 579-594 (1990)

122. Ryland, J. S. \& Warner, G. F. Growth and form in modular animals: ideas on the size and arrangement of zooids. Philos. Trans. R. Soc. B Biol. Sci. 313, 53-76 (1986).

123. Thiel, M. \& Gutow, L. The ecology of rafting in the marine environment. II. The rafting organisms and community. Oceanogr. Mar. Biol. An Annu. Rev. 43, 279-418 (2005).

124. Jablonski, D. Species Selection: theory and data. Annu. Rev. Ecol. Evol. Syst. 39, 501-524 (2008).

125. Gibbons, M. J., Buecher, E., Thibault-Botha, D. \& Helm, R. R. Patterns in marine hydrozoan richness and biogeography around southern Africa: implications of life cycle strategy. J. Biogeogr. 37, 606-616 (2010).

126. Gibbons, M. J., Janson, L. A., Ismail, A. \& Samaai, T. Life cycle strategy, species richness and distribution in marine Hydrozoa (Cnidaria: Medusozoa). J. Biogeogr. 37, 441-448 (2010).

127. Cornelius, P. F. S. Relationships between the cnidarian classes and the loss of the medusa stage. Porcup. Newsletters 5, 3-6 (1991).

128. Eldredge, N. et al. The dynamics of evolutionary stasis. Paleobiology 31, 133-145 (2005).

129. Romiguier, J. et al. Comparative population genomics in animals uncovers the determinants of genetic diversity. Nature (2014). doi: 10.1038 /nature 13685

130. Miller, R. L. The role of the gonomedusa and gonangium in the sexual reproduction (fertilization) of the Hydrozoa. Publ. Seto Mar. Biol. Lab. 20, 367-400 (1972).

131. Panteleeva, N. N. Life-Cycle adaptation of hydroids of the family Corynidae and the subfamily Obeliinae to habitat conditions. Dokl. Biol. Sci. 386, 457-459 (2002).

132. Bishop, J. D. D. Fertilization in the sea: are the hazards of broadcast spawning avoided when free-spawned sperm fertilize retained eggs? Proc. R. Soc. B Biol. Sci. 265, 725-731 (1998).

133. Bishop, J. D. D. \& Pemberton, A. J. The third way: spermcast mating in sessile marine invertebrates. Integr. Comp. Biol. 46, 398-406 (2006).

134. Kosevich, I. A. Morphogenetic foundations for increased evolutionary complexity in the organization of thecate hydroids shoots (Cnidaria, Hydroidomedusa, Leptomedusae). Biol. Bull. 39, 172-185 (2012).

135. Marfenin, N. Adaptation capabilities of marine modular organisms. Hydrobiologia 355, 153-158 (1997).

136. Nagy, L. G. et al. The evolution of defense mechanisms correlate with the explosive diversification of autodigesting coprinellus mushrooms (Agaricales, Fungi). Syst. Biol. 61, 595-607 (2012).

137. Cornelius, P. F. S. Life cycle, dispersal and distribution among the Hydroida. Porcup. Newsletters 1, 47-50 (1981).

138. Calder, D. R. Hydroids (Cnidaria: Hydrozoa) recorded from depths exceeding $3000 \mathrm{~m}$ in the abyssal western North Atlantic. Can. J. Zool. 74, 1721-1726 (1996).

139. Calder, D. R. \& Vervoort, W. Some hydroids (Cnidaria: Hydrozoa) from the Mid-Atlantic Ridge, in the North Atlantic Ocean. Zool. Verh. 319, 1-65 (1998).

140. Mendoza-Becerril, M. de los A. \& Marques, A. C. Synopsis on the knowledge and distribution of the family Bougainvilliidae (Hydrozoa, Hydroidolina). Lat. Am. J. Aquat. Res. 41, 908-924 (2013).

141. Nishiguchi, M. K. et al. DNA Isolation Procedures Techniques in Molecular Systematics and Evolution [DeSalle, R., Giribet, G. \& Wheeler, W. (ed)] [249-287] (Birkhäuser Basel, Basel, 2002).

142. Sambrook, J. \& Russell, D. W. Molecular Cloning: A Laboratory Manual. 3 Volume set [2344 pp] (Cold Spring Harbor Laboratory Press, Cold Spring Harbor, 2001)

143. Drummond, A. J. et al. Geneious v5.4. (2011). Available at: http://www.geneious.com

144. Altschul, S. F., Gish, W., Miller, W., Myers, E. W. \& Lipman, D. J. Basic local alignment search tool. J. Mol. Biol. 215, 403-10 (1990).

145. De Queiroz, A. \& Gatesy, J. The supermatrix approach to systematics. Trends Genet. 22, 34-41 (2007). 
146. Katoh, K. \& Toh, H. Improved accuracy of multiple ncRNA alignment by incorporating structural information into a MAFFT-based framework. BMC Bioinformatics 9, 212 (2008).

147. Kück, P. et al. Parametric and non-parametric masking of randomness in sequence alignments can be improved and leads to better resolved trees. Front. Zool. 7, 10 (2010).

148. Vaidya, G., Lohman, D. J. \& Meier, R. SequenceMatrix: concatenation software for the fast assembly of multi-gene datasets with character set and codon information. Cladistics 27, 171-180 (2011).

149. Stamatakis, A. RAxML version 8: a tool for phylogenetic analysis and post-analysis of large phylogenies. Bioinformatics 30, 2010-2011 (2014).

150. Miller, M. A., Pfeiffer, W. \& Schwartz, T. Creating the CIPRES Science Gateway for inference of large phylogenetic trees. Proceedings of the Gateway Computing Environments Workshop (GCE), 1-8 (2010). doi: 10.1109/GCE.2010.5676129.

151. Anisimova, M. \& Gascuel, O. Approximate likelihood-ratio test for branches: a fast, accurate, and powerful alternative. Syst. Biol. 55, 539-52 (2006).

152. Guindon, S. et al. New algorithms and methods to estimate maximum-likelihood phylogenies: assessing the performance of PhyML 3.0. Syst. Biol. 59, 307-321 (2010).

153. Xia, X. DAMBE 5: A comprehensive software package for data analysis in molecular biology and evolution. Mol. Biol. Evol. $92,1-27$ (2013).

154. Aberer, A. J., Krompass, D. \& Stamatakis, A. Pruning rogue taxa improves phylogenetic accuracy: an efficient algorithm and webservice. Syst. Biol. 62, 162-166 (2013).

\section{Acknowledgements}

We want to dedicate this study to Dr. Paul F.S. Cornelius (1943-2014), for his outstanding contributions to the study of leptothecate taxonomy and evolution, and to his willingness to help and teach several generations of taxonomists. We are grateful to many people and institutions that made this study possible, especially to all members (former and current) of the Laboratório de Evolução Marinha (Instituto de Biociências, Universidade de São Paulo - IBUSP) for their support. Alvaro Migotto, Alberto Lindner, Otto Oliveira, Stefania Puce and Gabriel Genzano for providing samples; PIs of the project CnidariaTree of Life (NSF grant EF-0531779) Paulyn Cartwright and Allen Collins, and members of the project Nathaniel Evans and Annalise Nawrocki, for providing DNA sequences and access to Sequencer software. Sabrina Baroni and Fernando Marques (IB-USP) have supported part of the molecular work. To Riviane Garcez, Juliana Jordão, Sérgio Stampar and James Roper for valuable comments. Carlos Moura, Peter Schuchert, Dale Calder and anonymous referee made many valuable criticisms on earlier versions of the manuscript and here they are gratefully acknowledged; any mistakes herein, however, are entirely our responsibility. This work was supported by Fundação de Amparo à Pesquisa do Estado de São Paulo (FAPESP) (PhD grant 2006/56211-6 to MMM; PhD and postdoc grants, respectively, 2010/06927-0, 2014/24407-5 to TPM; research grants 2004/09961-4, 2010/52324-6, 2011/50242-5, 2013/50484-4 to ACM), Conselho Nacional de Desenvolvimento Científico e Tecnológico (CNPq) (research grants 471960/2004-7, 557333/2005-9, 490348/20068, 563106/2010-7, 562143/2010-6, 477156/2011-8, 305805/2013-4 and 445444/2014-2 to ACM), Ministerio de Ciencia e Innovacion de España y el Fondo Europeo de Desarrollo Regional (FEDER) (research grant CTM200911128 ANT) to ALPC, and Programa Santander de Bolsas de Mobilidade Internacional (International mobility program for PhD students to MMM). This paper is a contribution of NP-BioMar, USP.

\section{Author Contributions}

M.M.M. and A.C.M. managed the research project. A.C.M. conceived the ideas, and A.C.M., T.P.M. and A.L.P.C. contributed to the original data. M.M.M. generated most of molecular data and performed most of the initial research and analysis. M.M.M., A.C.M. and M.S.B. drafted the original manuscript; the final version was written by all authors.

\section{Additional Information \\ Supplementary information accompanies this paper at http://www.nature.com/srep}

Competing financial interests: The authors declare no competing financial interests.

How to cite this article: Maronna, M. M. et al. Towards a phylogenetic classification of Leptothecata (Cnidaria, Hydrozoa). Sci. Rep. 6, 18075; doi: 10.1038/srep18075 (2016).

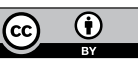

This work is licensed under a Creative Commons Attribution 4.0 International License. The images or other third party material in this article are included in the article's Creative Commons license, unless indicated otherwise in the credit line; if the material is not included under the Creative Commons license, users will need to obtain permission from the license holder to reproduce the material. To view a copy of this license, visit http://creativecommons.org/licenses/by/4.0/ 